NBER WORKING PAPER SERIES

\title{
WHOA, NELLIE! EMPIRICAL TESTS OF COLLEGE FOOTBALL'S CONVENTIONAL WISDOM
}

\author{
Trevon D. Logan \\ Working Paper 13596 \\ http://www.nber.org/papers/w13596 \\ NATIONAL BUREAU OF ECONOMIC RESEARCH \\ 1050 Massachusetts Avenue \\ Cambridge, MA 02138 \\ November 2007
}

I thank Rodney Andrews, Lisa D. Cook, Travis D. Logan, Thomas Logan, Jr., Anthony T. Logan, Vu Nguyen, Michael Sinkey and Michael Stengel for numerous helpful conversations. Paul J. Healy, Dan Levin, Matthew S. Lewis and James Peck provided helpful suggestions. I am greatly indebted to my team of superb undergraduate research assistants who did the heavy lifting of raw data collection: Gregory Barson, Donald Butler, Mark Byrnes, Megan Collins, Collin Davis, Matthew Dodovich, Ashley Higgins, Michael Kuch, Patrick Sprinkle, and John Taylor. Jun Nakabayashi provided excellent assistance in auditing the data based upon an algorithm suggested by Travis D. Logan. The usual disclaimer applies. The views expressed herein are those of the author(s) and do not necessarily reflect the views of the National Bureau of Economic Research.

(C) 2007 by Trevon D. Logan. All rights reserved. Short sections of text, not to exceed two paragraphs, may be quoted without explicit permission provided that full credit, including $\bigcirc$ notice, is given to the source. 
Whoa, Nellie! Empirical Tests of College Football's Conventional Wisdom

Trevon D. Logan

NBER Working Paper No. 13596

November 2007

JEL No. C8,D7

\begin{abstract}
$\underline{\text { ABSTRACT }}$
College football fans, coaches, and observers have adopted a set of beliefs about how college football poll voters behave. I document three pieces of conventional wisdom in college football regarding the timing of wins and losses, the value of playing strong opponents, and the value of winning by wide margins. Using a unique data set with 25 years of AP poll results, I test college football's conventional wisdom. In particular, I test (1) whether it is better to lose early or late in the season, (2) whether teams benefit from playing stronger opponents, and (3) whether teams are rewarded for winning by large margins. Contrary to conventional wisdom, I find that (1) it is better to lose later in the season than earlier, (2) AP voters do not pay attention to the strength of a defeated opponent, and (3) the benefit of winning by a large margin is negligible. I conclude by noting how these results inform debates about a potential playoff in college football.
\end{abstract}

Trevon D. Logan

The Ohio State University

410 Arps Hall

1945 North High Street

Columbus, $\mathrm{OH} 43210$

and NBER

logan.155@osu.edu 


\section{"Football represents and embodies everything that's great about this country."}

- Wayne Woodrow "Woody” Hayes

\section{"When they look back at that 9-1 season, they don't ask who the nine were."}

-Gen. Robert Neyland

College football occupies a singular place in the sports and cultural landscape. Since Rutgers defeated Princeton (6-4) on November 6, 1869 college football has been a central part of both sports and collegiate folklore. ${ }^{1}$ The reach of college football, when compared to other amateur or collegiate sports, is enormous. The stadiums that house the major college football powerhouses dwarf their professional counterparts, with several stadiums seating more than 100,000 spectators, and even more teams with consecutive sellout records that top 200 games. $^{2}$ College football is also big business_-revenues generated by college football average more than $\$ 35$ million per school in some conferences and bowl appearances can net more than $\$ 15$ million. The sustained tradition, pageantry, media attention, and excitement generated by college football are arguably unmatched in any other major American sport. ${ }^{3}$

Part of this tradition is controversy, particularly when it comes to determining the best team in a given season. Like most major sports, college football crowns a champion at the end of every season. Unlike most major sports, college football does not have a playoff system or any other hard rules to determine a champion. A key part of college football culture, then, is a never ending debate about which team in a certain year was truly better than all others. While being listed as the number one team in the country in the final Associated Press (AP) or Coaches' poll is seen by almost all

\footnotetext{
${ }^{1}$ Although the game of American football has its origins in rugby, which developed in England in the middle of the $19^{\text {th }}$ century, organized American football actually predates organized rugby in England.

${ }^{2}$ For example, Michigan's Michigan Stadium has seated more than 100,000 spectators since 1956, and Nebraska's Memorial Stadium (current capacity above 80,000) has been sold out for every home game since 1962 . On average, a team will play at home only 6 games per season-streaks of 200 or more imply home sellouts for more than 30 years.

${ }^{3}$ For example, more than half of all US televisions were tuned in to the Texas-Arkansas game in 1969, and the ArmyNavy game of 1926 attracted a crowd of more than 100,000 (MacCambridge 2005). In some locations, polictics take a back seat to college football. In 2006 the recount of the contested election in Ohio's $15^{\text {th }}$ congressional district was delayed by one day so that county election officials could watch the Ohio State-Michigan game.
} 
observers to be a national championship, there are no set rules for how either the AP or the Coaches' polls should determine which team is best. ${ }^{4}$

Since there are no formal rules for determining a champion, college football has adopted a set of "conventional claims" about what a team has to do to be ranked highly at the end of the season. It is generally believed that a loss at the "wrong" time or a close victory over a "weak" opponent can cost a team a chance to claim a national title. Moreover, observers have noted that it is better to lose early in the season rather than later, because a team's later performance will weigh heavily in how others view a team. Another piece of conventional wisdom is that a team is rewarded for playing (and winning against) strong opponents. Lastly, some have noted that large margins of victory are necessary to obtain or retain a high ranking because such victories receive "style" points as they reflect a team's dominance.

As with most pieces of conventional wisdom, the bases for these assertions are anecdotal, "everybody knows" stories. Implicit in these assertions, however, are empirical claims that can and should be tested. ${ }^{5}$ Even more, these claims embody implicit notions about how voters in the college football polls behave. Since the plural of anecdote is not evidence, this paper takes these pieces of conventional wisdom seriously and is the first paper I am aware of that puts them to the test. In particular, I test three pieces of college football's conventional wisdom: (1) that it is better to lose earlier in the season than later in the season, (2) that teams are rewarded for playing stronger opponents, and (3) that winning by wide margins earns a team "style" points that result in improved rankings. To test these propositions this paper exploits a newly created data set of week-by-week AP poll results for 25 of the most prominent college football teams over a 25 year period. This large and rich source of data allows us to look at each of these pieces of conventional wisdom to see if what "everybody knows" turns out to be true empirically.

\footnotetext{
${ }^{4}$ The NCAA lists ten organizations that bestow national championships in college football, some of them retroactively.
} 
I find that the conventional wisdom of college football is wrong. Rather than being penalized for losing later in the season, teams are actually rewarded for losing late in the season. In fact, this premium for losing late is sizable — teams that lose late in the season are re-ranked higher by roughly $3 / 4$ of AP poll voters than they would have been if they had lost early in the season. Even if one wished to argue that an early loss gives teams more time to make up ground in the rankings, the results here suggest that late losses leave teams with less ground to make up. Similarly, defeating strong opponents does not yield any advantage in terms of ranking, but losing to strong opponents helps. Margin of victory matters—but only if you lose. While winning by large margins does not confer any ranking advantage (despite numerous claims to the contrary), losing by a blowout hurts, and losing to a strong team does not soften the blow.

The lack of support for the conventional wisdom of college football does have implications for some current debates surrounding the sport. Recently, sports enthusiasts have strengthened their calls for a playoff system in college football, and others have called for early-season team rankings to be banned. These results suggest that determining a playoff based on the rankings of teams at the end of the season will need to be adjusted so as not to factor heavily the timing of losses (if the timing of a loss is exogenous to a team's true quality). As such, determining the four (or eight or sixteen) teams that would make a playoff could be complicated by the fact that the timing of losses matters. Teams may be out of playoff contention if they lose an early game, yet remain in contention if they lose a game late in the season.

What these findings imply for scheduling and conference alignments in the future, however, is unclear. Since strength of the opponent is not a factor, teams may be better served by avoiding games against strong opponents throughout the season, and this can work to the advantage of teams in weak conferences and naturally to the disadvantage of teams from strong conferences and/or

\footnotetext{
${ }^{5}$ Fogel (1975) makes this same point about implicit quantitative claims in history.
} 
non-conference schedules if strong opponents increase the probability of losing. It may be beneficial, however, to schedule strong opponents later in the season. Also, since large margins of victory are not rewarded in the AP rankings, teams have little incentive to "run up the score" on opponents, something coaches have claimed they must do to retain or obtain a high ranking.

These results have implications beyond college football. Tests of college football's conventional wisdom are actually modified tests of voter behavior. This paper offers a novel test of a particular type of behavioral model — the primitive voting model generated out of conventional wisdom. Although the example here is highly structured and applies to college football only, our ideas about voting behavior in general are largely guided by conventional wisdom, but usually difficult to estimate empirically since popular elections are one-time only events. Beyond a series of tests of voter behavior in college football, this paper makes another contribution. Despite the large literature on college football rankings, particularly among statisticians and mathematicians (Callaghan et al. 2004), and the work about the efficiency of the rankings, particularly among economists (Fair and Oster 2007), little work exist that tests voter behavior in the rankings themselves. While models of team rankings have been devised by a number of experts, we know little about how voters actually vote in the polls and what evidence they take as the most salient.

I begin the next section with a brief history of college football and by documenting the three pieces of college football's conventional wisdom that I later test, which are espoused by fans, coaches and sportscasters. In particular, I use the narrative record- news reports, sportswriter columns, fan blogs and message boards—-to establish the widespread nature of the conventional wisdom. I then discuss the data that I assembled to test these propositions and present the central empirical results of the paper which refute the conventional wisdom of college football. Next, I consider alternative specifications to test the robustness of the results, and I conclude by discussing what these results imply for current debates about a playoff in college football. 


\section{College Football Facts and Myths A. College Football's Evolution}

From its beginnings in the late nineteenth century, college football soon blossomed into a major American sport by the turn of the last century. Since professional football did not begin in a sustained organized form until the 1920s, college football was the source of the sport's origins and first innovations. In fact, such standard features of the game as the line of scrimmage, first downs, and even the points awarded for scoring were all decided in college football's formative years in the late nineteenth century. ${ }^{6}$ The creation of mascots, fight songs, and the grouping of teams into leagues and conferences all took hold during college football's formative years. But college football at this time, even at the highest levels, was anything but the revenue generating spectacle that it is today. Even into the early $20^{\text {th }}$ century, many prominent teams had no official coach, and most of those who coached did so on a part-time basis. The sport was a particularly controversial feature on some college campuses due to its violent nature. As early as 1905 President Roosevelt was threatening to ban the sport based on its brutality (more than 100 players had been killed in the 1905 season), which led to the creation of the National Collegiate Athletic Association (NCAA) to devise rules for the game.' Despite this threat, by the early twentieth century college football's popularity was beyond question.

The early years of the sport were dominated by private universities, in contrast to today's top programs. Although not officially a league until the 1950s, the Ivy League was the first power conference in college football—Harvard, Yale, and Princeton have a combined total of more than thirty national championships in the sport, the vast majority earned before the Great Depression. Concerns about the place of sports at these schools, however, led to an agreement in late 1945 that

\footnotetext{
${ }^{6}$ For a basic introduction to the game of football by (and for) an economist, see Romer (2006).

${ }^{7}$ In the 1905 meeting between President Roosevelt and representatives from Harvard, Yale, and Princeton, it was suggested that the width of the playing field be increased by 40 feet to prevent injuries. Harvard representatives rejected
} 
signaled the beginning of the end of major college football at elite universities. The Ivy Group Agreement ended football scholarships among the member schools, and in 1954 banned bowl games, spring practices, and decreed that student athletes should be "representative" of the student body. While these schools de-emphasized the sport, other schools built up their programs, and by the mid-twentieth century college football's popularity had been codified with larger-than-life coaches, storied rivalries, weekly polls (the AP poll began in 1936), bowl games (the Rose bowl has been played annually since 1916), national championships, and the formation of athletic conferences whose champions would compete in bowl games.

Several features of what can be termed contemporary college football are fairly recent in origin, however. Traditionally, the national champion was determined before the bowl season began, and historically few teams had the option of playing in the postseason. ${ }^{8}$ Bowl games were seen, originally, as a prize for a well-played season. In fact, the Big Ten conference began allowing more than one team to play in a bowl game in 1975, and the conference at one time did not allow back-to-back bowl appearances by the same team. ${ }^{9}$ Notre Dame, under a multi-decade self-imposed "no bowl games" policy, would be crowned national champions more than five times while not appearing in any postseason matchups. As such, the focus on bowl games and the postseason as a means of determining the best team in a given season is a recent phenomenon. Similarly, while the power in college football has changed from elite private universities such as Harvard and Princeton to public universities such as Alabama and Oklahoma, other changes have sought to bring parity to

the idea since they had recently completed construction of Harvard Stadium. As a compromise, the forward pass was invented (MacCambridge 2005).

8 The AP began ranking teams after bowl games in 1965, and the Coaches' poll began doing so five years later.

${ }^{9}$ This is largely due to the complaints of Michigan fans following a 10-10 tie in the 1973 Ohio State - Michigan game. The athletic directors of the schools in the Big Ten voted on who would represent the conference in the Rose Bowl, the only bowl the conference played in. When Ohio State won the vote, Michigan fans and supporters complained, and eventually the conference allowed more bowl tie-ins. 
the sport. ${ }^{10}$ Beginning with scholarship restrictions, recruiting guidelines, the extension of the regular season to eleven games, and academic requirements in the 1970s, the NCAA brought about a new college football landscape, where teams with little or no tradition could gain a foothold if the administration was committed to developing a football program and if a program could recruit top athletes. $^{11}$

The largest change in college football in its modern form is the exposure of the sport to a general audience. In the early days of television, the NCAA decided which games would be broadcast. Traditionally, the television coverage favored teams with strong national reputations and storied histories (such as Notre Dame or Michigan), and many individual teams, as well as conferences, wanted to allow consumers further choice. The decision in NCAA v. Board of Regents of University of Oklahoma and Georgia Atbletic Association (1984) allowed college football conferences to schedule their own games. This de-regulation, along with the growth of cable and satellite television outlets, meant that college football was now the focus of more television hours than ever before. The exposure of teams with less storied traditions has been most pronounced, and many teams that now count themselves among the established teams in the college football landscape (Miami (FL), Wisconsin and Virginia Tech, for example) did not have a large number of winning seasons before these institutional changes. ${ }^{12}$ Another change brought about by college football's massive media

\footnotetext{
${ }^{10}$ Football is the only NCAA sport that sub-divides the Division I schools. Beginning in 1978, Division 1A (now referred to as the bowl division) required (1) an average attendance of 15,000 per home game over a 2 year period, (2) that $60 \%$ of games be played against Division 1A opponents, and (3) the schools to grant athletic scholarships. Division $1 \mathrm{AA}$ (now referred to as the championship division, as this division's champion is decided through an NCAA organized playoff) does not require scholarships or attendance minimums.

${ }^{11}$ Before the NCAA intervened, players could be offered scholarships and other incentives (up to and including pay) to be football players. Originally, the NCAA sought to ban the practice of awarding athletic scholarships in 1947, but this was met with fierce resistance (and outright violations). In 1951 the NCAA allowed scholarships, and also established rules for recruiting athletes. The number of scholarships that could be offered was limited in 1977 to 95 scholarships. This has been reduced over time, and the football scholarship limit is currently 85. Depken and Wilson (2006) show that NCAA enforcement increased the competitive balance of college football.

${ }^{12}$ Incidentally, conventional wisdom held that college football would be less competitive with the deregulation of television coverage. For example, when Notre Dame signed its exclusive television contract with NBC in 1990 (effective for the 1991 season and renewed thereafter), it was widely believed that Notre Dame would dominate college football because they could ensure to any potential recruit that they would receive a large amount of television exposure (a major
} 
exposure is the culture of college football itself — smaller rivalries are made known nationwide, teams with little traditions can rise to prominence, and recruits may choose to play for schools that will allow them to play earlier than those with deeper rosters.

Against this backdrop, it was not until the 1970s that football achieved steady progress in racial integration. In a sport that is now majority black at the highest levels (both college and professional) the exclusion (and later inclusion) of black athletes from certain teams' rosters would obviously change the complexion of the game. College football's integration mirrored that of the rest of the country, with Texas' 1969 national championship team the last all-white team to win a title. While Miami and Kentucky (1966) did sign black players to their rosters in the 1960s, southern schools did not begin integrating their rosters, en masse, until the $1970 \mathrm{~s}^{13}$ Before full integration, integrated teams would, by agreement, sit their black players when playing at the home site of a segregated team if a school so stipulated. ${ }^{14}$ Racial segregation also created curious recruiting strategies, where integrated teams would recruit black southern athletes to their institutions because they would not be recruited by the major college football programs in their region.

These changes have arguably heightened the drama of autumn Saturday afternoons. As parity progresses the goal of a national championship is also arguably within the reach of more schools than ever before. The goal of every program is to position itself best to play for a national title once the bowl season begins. While not losing any games is, without question, the best way to

recruiting point at the time). Since Notre Dame signed the television contract in 1990 they have not won a national championship. Some of these claims are controversial, however, and products of conventional wisdom themselvesSutter and Winkler (2003) argue that scholarship limits have increased parity among the top 20 teams, but not overall.

${ }^{13}$ Resistance to integration in college football was pronounced. In December of 1955, the governor of Georgia asked Georgia Tech to reject an invitation to the Sugar Bowl because their opponent, Pittsburgh, had black players on the roster. Shortly thereafter, Louisiana legislators banned all colleges from competing against schools with black players. ${ }^{14}$ In college football mythology, the USC-Alabama game on September 12, 1970 holds special interest. In that game, two USC African American running backs, Clarence Davis and Sam Cunningham torched the all-white Alabama squad 42-21. After the game, Alabama coach Paul "Bear" Bryant escorted Cunningham into the Alabama locker room and told his players "Gentlemen, this is what a football player looks like," at which point each player rose to shake Cunningham's hand. While some have claimed that "Sam Cunningham did more to integrate Alabama in 60 minutes that night than Martin Luther King, Jr. accomplished in 20 years," (MacCambridge 2005, p. 48), Bryant had already integrated Alabama football, signing a black running back, Wilbur Jackson, in the Spring of 1970. 
accomplish that goal, it is actually rare that a team completes an entire season unscathed, and even rarer that two and only two teams do so. Also, even if one does remain undefeated, it does not guarantee a spot in a desired bowl game—one can be shut out of the competition. ${ }^{15}$ To accomplish this goal in light of the reality that teams with losses regularly end the season highly ranked, observers and fans have adopted "golden rules" (what I term here conventional wisdom) as to how a team can best position itself to be highly ranked in the polls at the end of the regular season. Even if one does not make it to the designated "national championship" game, the gains to being close are substantial as BCS bowl appearances come with payouts in excess of $\$ 15$ million. These "golden rules" are largely a product of the recent, post 1970s college football landscape-they incorporate ideas of how teams should perform throughout the season to impress a subjective group of voters in polls that determine a team's position in the hunt for a national title and major bowl berth.

\section{B. College Football's Conventional Wisdom 1. "If you're going to lose, lose early"}

The conventional wisdom of college football dictates that teams who lose early in the season stand a better chance of being highly ranked at the end of the season than teams who lose later. The logic is that teams who lose early have a greater opportunity to climb up in the polls after a loss, and also a greater chance of leapfrogging teams that lose at later points in time. Also, since ranking in the polls reflects recent performance, it is better to avoid losses late in the season. Similarly, the wisdom holds that voters view late losses unfavorably as they are a signal of low team quality.

This view is widely held among fans and observers. Below is a sampling of the logic offered by fans in sportsblogs and message boards, where this piece of conventional wisdom is most pronounced:

\footnotetext{
${ }^{15}$ A recent example would be the undefeated Auburn team of the 2004 season.
} 
"It is better to lose early than late."16

"Even if you follow the logic that one loss takes the college team out of contention, you still have flawed logic. When Michigan lost, there were dozens of people on here who said, 'It's better to lose early than it is to lose late. Michigan can still be in it if they win all their games." 17

"There is a small part of me that would love to see that [Michigan in the Rose Bowl], just to prove the fact that a loss early in the year doesn't count as much as a loss at the end of the year." 18

"This season will demonstrate perfectly why it is better to lose early than late. It might make big time rivalries like Ohio State-Michigan move their matchup to early or mid-season so that both team still have a chance to recover and make the national championship game."19

"I still say all things being equal, if I am a coach with national championship aspirations, I would rather lose to an unranked team in week 5 than the number one team in week $10 . " 20$

"In college football, it is not about who you lose to, but when you lose. If you are going to lose, you always want to lose early. Pollsters have notoriously horrible memories."21

Fans are not the only ones to assert that losing early in the season is better than losing later. Sports

columnists have also made such claims.

"The [LSU] Tigers haven't lost to the [Mississippi State] Bulldogs since 1999 - and they historically own them - but if you're going to lose, lose early."22

"However, if the [Georgia] Dawgs keep on winning, beat Florida, win the [Southeastern Conference] East [division], and upset LSU, then yeah...the South Carolina loss doesn't look as bad. The pollsters have short memories... That's why the computers are so important in the BCS formula; they don't care when you lose." 23

"History has shown us that it is better to lose early than lose late.",

"If you lose a game, just make sure it isn't close to the end of the season." 25

\footnotetext{
16 http://www.sportingnews.com/yourturn/viewtopic.php?t=280365

17 http://www.fannation.com/throwdowns/show/57318

18 http://mercuryworm.wordpress.com/2007/09/23/college-football-top-25-updated-for-week-5/

19 http://www.bleacherreport.com/articles/2926--Bleacher_Report_s_College_Football_Top25_Week_8_Comments-

171007

${ }^{20}$ http:/ / forums.freep.com/viewtopic.php?t=54234

21 Ibid.

${ }^{22}$ Caparell (2007).

${ }^{23}$ Fiutak (2007).

${ }^{24}$ Reback (2007).

${ }^{25}$ Barra (2001).
} 
"It used to be that you could lose early and come back into the national championship picture with some help. This year, however, there's already been an inordinate amount of "help" being thrown around. So much so, that no more is needed. Teams just need to focus on taking care of their own business." 26

The assertion that it is better to lose earlier in the season than later is an empirical assertion about how pollsters weigh wins and losses as a function of the week of the season in which they are played. For example, many of the thoughts on this topic contain a notion that poll voters are "forgetful" or "myopic" in their behavior, to the extent that they weigh evidence differently. In this way, the order of the signal matters. The logic is that it is better to send a bad signal early than late because there are fewer opportunities to make up for it.

The implicit ideas in this particular piece of conventional wisdom do contain pieces of recent economic models of behavior. The conventional wisdom would be consistent by inference from the Law of Small Numbers, to the extent that if a promising team loses early, and promising teams have few loses, then losing early allows one to predict future wins with higher probability (Rabin 2002). Similarly, one could pose that there are issues of problems in Bayesian updating or projection bias (Lowenstein, O’Donoghue and Rabin 2003). This notion of the value of the timing of a loss runs counter to the notion of confirmatory bias, however, because in that case later losses would be seen as particularly non-representative of a team's quality (Rabin and Schrag 1999).

\section{There's a Benefit to Playing (and Defeating) Strong Opponents}

All else equal, teams should be rewarded for playing (and defeating) opponents who have strong records. While observers have long noted that this is true, the way in which opponent strength should be measured remains unclear. By convention, one has played a strong team if that that team has a high winning percentage. In the discussion of this issue, several terms are used, and here I use

26 Tamanaha (2007). 
them interchangeably. ${ }^{27}$ For example, one cannot have a "strong schedule" unless it includes "strong opponents," and defeating "strong opponents" results in, by default, a "quality win." The BCS formula, in certain incarnations, took "strength of schedule" into account explicitly, and it has caused teams to remain interested in the records of their opponents long after the game has been played.

Back when college football was propelled by clichés instead of a computer hard drive, Oklahoma Coach Bob Stoops would have stopped caring about Alabama about a millisecond after his Sooners polished off the Crimson Tide on Sept. 7. Coaches were taught to look straight ahead about the same time they first picked up a whistle. Stoops cares a lot about Alabama now. The Tide has won five of six games, including a 34-14 romp Saturday over Tennessee, and as a result, the Sooners have strengthened their lead in the latest Bowl Championship Series ranking.

"You like to see those teams continue to win and go on and look good," Stoops said yesterday. Although they did not play over the weekend, the Sooners (7-0) have a better B.C.S. ranking and have a wider edge over Miami (7-0), which, at least according to the computer rankings, struggled in a 40-23 victory over West Virginia. ${ }^{28}$

In the conventional wisdom, however, strength of opponents is already captured in the AP and

Coaches' polls. In fact, some critiques of the BCS formula (which in its various incarnations has averaged the AP and Coaches' polls and included computer rankings, bonus points for defeating highly ranked teams, and strength of schedule) have noted that the BCS's explicit inclusion of opponent strength leads to a double counting of strength of schedule, since the Coaches' and AP polls already take such factors into account.

Simply, the polls and computers already account for schedule strength and "quality wins," or else the three non-BCS one-loss teams would have placed in the top 6 in the 2003 BCS standings. Some have argued that the BCS formula of including strength of schedule and quality wins explicitly led to a double countings since polls already included strength of opponents. One of the presumed motivations for including separate factors for schedule strength and quality wins was to reduce the assumed bias of the polls towards traditional football powers. However, as discussed above, the top non-BCS teams over the past six years were ranked similarly in the polls and computers. Therefore, one might rightly worry

\footnotetext{
${ }^{27}$ For the purposes here, I am combining discussions of strength of schedule, opponent's strength, and quality wins since the conclusions of these three lines of argument are the same.

${ }^{28}$ Caldwell (2002)
} 
that the quality wins and schedule strength factors are making it harder for non-BCS schools to do well in the standings, as their schedules are typically ranked significantly lower and they have few opportunities for so-called "quality wins". 29

The real argument among college football fans is not that quality wins or strength of opponents do not matter, but that pollsters do not weigh them correctly. Indeed, the belief that strength of opponent is included in the ranking is implicit—what fans debate is why a particular team is ranked above/below another when it has a stronger/weaker strength of schedule. ${ }^{30}$

Two important caveats to the discussion of strength of schedule are the roles of schedules themselves and of conferences. First, it should be noted that college football schedules are decided many years in advance. For example, the full schedules for the next three seasons are already posted for most major college football programs. Since players only have a set amount of eligibility, and because the number of scholarships is limited, the quality of a future opponent, particularly well into the future, is unknown. This also means that the quality of opponents in a given year may be weakly correlated with the scheduler's intent—one cannot predict the future quality of a team when they do not know who the majority of the players will be. To that end, a team that devised to create a weak schedule may inherit a strong one through no fault of their own. Secondly, teams play a significant number of their games within a conference, whose strength in any given year is not known.

\section{Margin of Victory Matters}

Even before the BCS incorporated (and later discarded) the use of margin of victory in its poll, it was widely held that teams should win by large margins as a sign of their dominance. ${ }^{31}$ Good teams, it is argued, should win by large margins, especially when playing against weak opponents. Poll

\footnotetext{
${ }^{29}$ Callaghan, et al. (2004)

${ }^{30}$ Indeed, the discussion of this points among fans and commentators is so pronounced that it is a topic among itself among fans. For example, most college football message boards and columnists will discuss which conference is stronger than another, and which teams have the "toughest" schedules.

31 The original BCS formula incorporated margin of victory in the 1998 to 2001 seasons.
} 
voters, it is argued, take such margins of victory into account. As with the previous two pieces of conventional wisdom, blogs and message boards are rife which such speculations. Unlike the other pieces of conventional wisdom, however, college football coaches openly admit that they believe (and play under the assumption of) this conventional wisdom. In fact, even after margin of victory was eliminated from the computer polls used in the BCS formula, coaches admitted that impressing voters in the "human polls" (such as the AP poll) required them to think about margin of victory.

Just because Steve Spurrier is in the National Football League and the computers used for the Bowl Championship Series no longer calculate margin of victory does not mean that college football teams have become more compassionate and less points-crazy against overmatched opponents. Before the season, the coaches successfully campaigned for the elimination of the margin of victory component used by some of the B.C.S. computer services. The theory was that, if the rankings formula did not reward running up the score, why would a coach risk injury to his players and embarrassment to an opponent by pouring it on late in a game?

'It was the right thing to do,' Tennessee Coach Phillip Fulmer said. 'I know from first-hand experience when that is in the back of your mind and you're up 21 points in the fourth quarter or 14 points in the fourth quarter.' Several coaches said margin of victory may have been eliminated from the software this season, but not from the hardware of human beings.

Georgia Coach Mark Richt, whose Bulldogs are 4-0 and No. 3 in The Times's ranking, says voters in the Associated Press news media poll and USA Today/ESPN coaches poll still take final scores into account. 'I think people still vote on the impressiveness of the win,' Richt said.

Texas Coach Mack Brown agrees, noting that his Longhorns (4-0) jumped over Oklahoma to No. 2 in the news media poll this week after defeating Tulane, 49-0. The Longhorns did not run it up on the Green Wave; Brown pulled his first team early in the fourth quarter when Texas was ahead by 28-0. But he understands the impact the box score had on voters the next day.

'If we beat Tulane, 7-6, we would have dropped in the polls,' Brown said. South Carolina Coach Lou Holtz said he is often torn between compassion for the other team and wanting his reserves to improve.

'I really believe as long as the other team is trying to score, you have an obligation to let your second team try and score,' Holtz said. ${ }^{32}$

Even well after the BCS discarded margin of victory, coaches admitted that they believed that margin of victory was an important component of how their team would be perceived. 
Major college football's reliance on subjective polls to determine a national champion also plays a part in how teams manage blowouts.

"With the BCS and all the ramifications that come with the rankings," Tennessee coach Phillip Fulmer said, "they have basically put you in position to make you get your team to look as dominant as you can., 33

This has caused some fans and sportswriters to encourage teams to win by large margins, or to assert that poll voters pay more attention to teams that win by wide margins. However, some pollsters have noted that wide margins of victory are not needed to send the message that a team is dominant.

Voters are easily drawn to victory margins like $79-10 .^{34}$

"A 28-0 or a 42-10 victory is impressive enough for me," says Kirk Bohls, a writer for the Austin (Texas) American-Statesman and a voter in The Associated Press poll last year. "If anything, I am turned off by a 70-0 score and investigate whether the winning team consciously ran up the score.... That's the ultimate turnoff to me as a voter." ${ }^{135}$

The key here is that coaches are working under the perception that the margin of victory matters in the minds of the pollsters who will determine their team's ranking on a week-to-week basis. Like the other claims noted above-we should see if this concern noted by the coaches (which is independent of the BCS poll's explicit inclusion of margin of victory) is true empirically.

\section{Data and Empirical Strategy}

To test the conventional wisdom described above I assembled a dataset that contains the weekly game and ranking information for 25 of college football's most prominent programs for the 25 seasons from 1980 to $2004 .^{36}$ In all, the data contains information on more than 6,000 football games. I have information not only on the features of the team on a week-by-week basis, but also

\footnotetext{
32 Drape (2002)

33 Russo (2007)

${ }^{34}$ http://www.bleacherreport.com/articles/2849-College_Football-Pulling_Rank_How_the_Polls_Should_Work141007

${ }^{35}$ Dienhart (2002)

${ }^{36}$ See the data appendix for further details.
} 
information on their opponents_critical for testing claims that strength of opponent matters in determining rankings. While some studies have looked at end of season rankings over long time periods (Langellet 2003, Sutter and Winkler 2003), and others have looked at weekly poll progressions for short time periods (Goff 1996, Lebovic and Sigelman 2001, Campbell, et al. 2007, Paul, et al. 2007), this is the first study that looks at over 20 years of weekly data for such a large number of teams, and is also the first study to look at the effect of a large number of game characteristics on voting outcomes. ${ }^{37}$

Table 1 shows the 25 teams included in the analysis. The data contains information on all but 5 teams who claimed any share of a national title from 1980 to $2004 .{ }^{38}$ Earlier, I argued that college football's current incarnation begins sometime after the 1970s due to the institutional changes taking place in the sport, although some changes came later (such as television de-regulation). While starting in 1980 is somewhat arbitrary, it is at a point in time that is late enough for many of the changes begun in the 1970 to have an effect on the game. Similarly, since the focus here is on test of the rankings in college football, the sample is biased towards teams that were highly likely to be ranked for a majority of the time covered. Care was taken to produce a geographically balanced set of teams, and all major regions of the nation (as well as all major conferences) are represented in the data. The data contains the date of the game, score of the game, location of the game (home, away or neutral), opponent,

\footnotetext{
${ }^{37}$ Previous studies have looked at how rankings evolve over a season and not what features poll voters take as most important. Goff (1996) looks at final season ranking as a function of mid and preseason ranking, and Lebovic and Sigelman (2001) also look at inertia in the polls. See Paul, et al. (2007), Campbell, et al. (2007), and Frechette, et al. (2007) for examples of work that uses smaller samples of AP poll statistics.

${ }^{38}$ Of the five teams not included in the data that won a national championship, Southern Methodist University (SMU) was beset with an NCAA "death penalty" in 1986 that devastated the football program. Since SMU was already on NCAA probation fore recruiting violations (1985-1988), the second set of charges that surfaced in 1986 led the NCAA to issue the most severe sanctions allowed. The penalty was severe, not only the loss of scholarships (55 scholarships over a 4 year period), but the 1987 season was cancelled and the 1988 season called for only a limited number of away games to be played (SMU cancelled this season as well). All television games and bowl appearances for SMU football were disallowed during the 1988 and 1989 seasons. In addition, SMU players could transfer to another school without having to wait a probationary season to play (which is the procedure under normal NCAA rules). Since the sanctions by the NCAA, SMU has had one winning season (1997-1998, going 6-5), and several commentators believe that the SMU "death penalty" led to the collapse of the Southwestern Conference due to lost revenues (and, through its demise, the emergence of superconferences such as the SEC and Big 12).
} 
opponent's record at the time the game was played, opponent's record for that season, the team's and opponent's ranking before and after the game in the AP poll.

The AP has ranked football teams continually since 1936. AP teams are ranked by way of a Borda count with a set (fixed) number of press representatives voting every week of a season, usually chosen to be geographically diverse. Each week members rank teams from 1 to 25 in a ballot. In calculating points, teams ranked first receive 25 points, those ranked second 24 points and so on. The team with the most points in that week's ranking is therefore ranked first. AP voters are explicitly instructed to base their votes on performance, not a team's stature or speculation, and they are told that it is perfectly acceptable to make significant changes in the ballot from week to week (Mandel 2007).

For the team ranked first in a given week there is little disagreement in general. While this would seem to imply that the voting is fair for all ranks, Borda counts can be manipulated by ranking teams differently, but AP ballots are not secret and have never been (Wieberg 2005). As such, AP voters have been regularly interviewed throughout the season about why they ranked teams as they did. While this does not eliminate sources of potential bias, it does act to reduce it. ${ }^{39}$

There are some limitations with the data at hand. For example, it does not include many teams from "mid major" conferences, and as such the conclusions that one may wish to apply to all teams should be tempered. Similarly, the data here will have little to say about programs that were competitive for a short number of years or teams that have not had many winning seasons. In short, the data here speaks to the most successful programs in college football for the last quarter century. As that is the focus of the conventional wisdom, however, such narrow attention is warranted.

\footnotetext{
39 The Coaches' Poll is not used because the ballots were not released publicly until the last regular season ballot of the 2005 season. Similarly, the Coaches' Poll has been criticized because there is evidence that the coaches themselves do not fill out the ballots (Barnhart 1998) and that coaches have a strong bias towards their own teams, the teams in their conference, and their other opponents (Mandel 2005). But, as recently stressed by Buchanan and Yoon (2006) it is not possible to assert that there is no bias in the AP poll, particularly when pollsters achieve a surprising amount of consensus with regards to the number one team so often.
} 
Table 2 shows the summary statistics for the key variables used in the following analysis. Teams are much more likely to win than lose, as expected from this sample, and the average margin of victory is 9 points, with the teams in the sample scoring around 4 touchdowns per game. I define a "blowout win" here as winning by more than 17 points (two touchdowns, two extra points, and one fieldgoal), and these victories happen more than half of the time. Teams lose by more than 17 points about 10\% or the time. A "close win" is winning by less than three points (less than the value of a fieldgoal), and these types of victories are relatively rare, and so are "close losses."

One would like to think that a teams ranking reflects an expectation about a team's quality, and that a team ranked above another would have a high probability of defeating that team. Previous research, however, has shown that rankings actually perform poorly as predictors of victory—betting lines do much better (Fair and Oster 2007, Paul et al. 2007). The claims made about rankings, however, do not assume nor do they require that rankings themselves be best predictors of who will win a headto-head match up. The key problem for rankings, however, is that they begin at an initial value and change over the season. Ideally, we would like to match teams and have them differ only in one way (such as the timing of their losses) to test these claims. It is not possible, however, to do such a paired comparison, so another method is needed. ${ }^{40}$

At the heart of each piece of conventional wisdom is the idea that some feature of a game- the time of the season it is played, the strength of the opponents, the margin of victory-have a larger effect on the change in ranking than other features that may vary over a season. Since the AP poll ranks teams based on the points each team is awarded by voters, looking at the changes in points is equivalent to

\footnotetext{
${ }^{40}$ While one could imagine matching teams based on their rankings for successive year (the number 5 ranked team in 1980 and the number 5 team in 1981), those teams themselves will play different teams, contain different personnel, etc. As such, differences we may or may not find due to differences based on the timing of losses, for example, will be suspect to numerous criticisms. Here, I make no causal claims, and only look at the relationship between the measures of interest and AP point changes, controlling for these other features that may influence the relationship.
} 
looking at changes in rankings. ${ }^{41}$ Also, since higher point totals lead to higher rankings, the interpretation is more intuitive than for rankings. ${ }^{42}$ We can think then, of the points in the AP poll as a function of the characteristics games played and the initial number of points

$$
E\left(P_{t}\right)=P_{0}+\sum_{k=0}^{t-1} \Gamma_{k} \beta
$$

Where $P$ is the points for the team in the AP poll in the preseason poll $(0)$ and week $t$, and $\Gamma$ is a set of game characteristics (win, loss, opponent strength, etc.). I test for the conventional wisdom by looking at the relationship between game characteristics and changes in AP point-totals. Since teams play one game only between rankings, this strategy will capture the relationship between game characteristics and AP point changes. ${ }^{43}$ In particular, I test the conventional wisdom outlined above with

$$
E\left(P_{t}-P_{t-1}\right)=\Gamma \beta
$$

where I regress the change in AP points from week $t-1$ to $t$ on the characteristics of the game played between $t-1$ and $t$.

Each of the pieces of conventional wisdom can be used to generate hypotheses about what we would expect the sign of $\beta$ to be for some game characteristic. If losing late in the season is worse than losing earlier in the season then losing late would result in a large, negative effect on point changes. This would reflect the fact that teams would be downranked more for losing later in the season. As such we would expect the coefficient on losing late to negative. If opponent strength mattered to voters teams would be awarded more points for defeating strong opponents, so the conventional wisdom hypothesizes that the coefficient on defeating a strong opponent would be positive. If teams were

\footnotetext{
${ }^{41}$ Campbell et al. (2007) and Paul et al. (2007) are recent studies of football ranking points, but they use a small number of variables and are not concerned with game characteristics themselves.

42 See the appendix for ranking results.

${ }^{43}$ It is very rare, but in the beginnings of some seasons teams may play two games before the first updated ranking in released. This is so rare, however, that it does not effect the results discussed below.
} 
"rewarded" for decisive victories then defeating opponents by wide margins would result in a gain in points, so the coefficient on blowout victories should be positive.

\section{Empirical Results A. Central Findings}

Table 3 shows the base specifications for the tests employed here. As a first check, column I shows that wins increase the number of AP points, and losses decrease the number of points in the following poll. Column III adds close and blowout wins and losses as well as opponent strength. Blowout losses matter — a team loses about $20 \%$ more points if they lose by a wide margin but there is no benefit to winning by a wide margin — the effect of a blowout win is not statistically different from zero. While close wins are not rewarded or punished, close losses help-they reduce the change in points from losing by about 10\%. Opponent strength does seem to matter, each additional win by an opponent increases the points in the next ranking by 5 points. But playing a strong opponent should have a small impact relative to defeating a strong opponent. In Column IV I interact winning and losing with opponent strength, and opponent strength and defeating a strong opponent have no effect on AP point changes. Losing to a strong opponent helps, but the effect is only marginally significant. Column $\mathrm{V}$ includes an indicator for winning or losing late in the season. Late in season is defined here as greater than or equal to the tenth poll-week of the season. For most college football seasons, this week comes as the last week of October or first week of November, and well more than $2 / 3$ of the games for the season have been played. ${ }^{44}$ Teams will have, on average, 3 or 4 more games to play to complete the season. While winning late in the season has no effect on changes in AP points, losing late in the season actually benefits teams — the cushion provided by losing late in the season is around $20 \%$ of the value of losing. Given the point estimate in Table 3 and the number of AP poll voters, losing late in the season implies that more than 3/4 of AP poll voters rank a team one place higher in their rankings after a late 
season loss than for an early season loss. ${ }^{45}$ In fact, if one were to lose in a blowout at the end of the season, the net result would not be that different from losing by a small margin early in the season. Each piece of conventional wisdom is rejected in the results of Table 3. Losing later in the season actually benefits teams; opponent strength does not matter, win or lose; and blowout victories do not result in any "style" points. In fact, the evidence that we do have points strongly in the opposite direction. Rather than significantly hurting teams, losing late in the season actually helps them-it lessens the blow of a loss significantly. Similarly, while defeating a strong opponent does not help, losing to a strong opponent actually softens the blow of a loss. For example, losing to a team with an 83 record would actually decrease the negative point change from losing by more than $15 \%$ of the change for a loss. Lastly, rather than blowout wins helping, close losses actually help, and blowout losses hurt the most. All told, the conventional wisdom of college football has little empirical support.

It could be that the effects described in Table 3 actually obscure the important interactions between the effects. For example, losing late in the season against a strong opponent in an away game might mitigate the effect of losing late. To consider the possibility that these interactions play a role in the results Table 4 presents estimates where late games are interacted with other characteristics. ${ }^{46}$ The primary results are robust to the inclusion of these interactions. For example, the effect of a loss later in the season is still large and statistically significant. In terms of blowout wins and losses, winning late in a blowout against a strong opponent at an away game actually hurts a team, although the size of this effect is small. The effect of losing in a close game while playing at the opponent's field is negative, but playing against a strong opponent helps. For example, losing a close game late in the season to a strong (8-3 record) opponent at their field would result in losing about 100 fewer points that if one lost to an

\footnotetext{
${ }^{44}$ For example, teams will usually play their $8^{\text {th }}$ or $9^{\text {th }}$ game by the tenth poll week. Considering that teams now play 11 or 12 games, this implies that $3 / 4$ or more of the schedule has been played.

45 Although it varies from year to year, the average number of AP voters from 1980 to 2004 was 65.

46 This was done in Table 3 but the results not shown due to space limitations.
} 
opponent with an even record. But this is somewhat counter to the conventional wisdom, strength of the opponent matters, but only when you lose.

\section{B. Robustness}

Before turning to the specification tests of the central findings, it is useful to check the validity of the results to some general robustness checks. I do this in three ways, (1) I check for the robustness of the results based on a team's previous point change and the sequence of those point changes, (2) I check the results by the length of winning streak, and (3) I included fixed team and season effects and cluster the standard errors.

The results of Table 3 could be due to the fact that teams' previous results are over-represented. For example, the results for losing late could be positive because they would represent a second loss, which may be weighted differently than the first. To check to see if the results are sensitive to previous results, I estimated regressions similar to those in Table 3 conditioned on the sign of previous point changes (a weaker condition than conditioning on previous wins or losses). Table 5 shows the results by the sign of a team's lagged point change. As the Table shows, the results are not sensitive to how a team's points have previously evolved. Even more, they are robust to different ordering of the point changes the prior two weeks. This is also an encouraging check that conditioning on point changes captures the relationship between the current game's characteristics and the point change.

The results of Table 3 could be due to an over-representative of teams with long winning streaks. To deal with this issue, Table 6 shows the results by the length of the winning streak. We would expect that, if a long winning streak is an indication that a team is of high quality, that characteristics that negatively impact a point change would be lessened for teams with long winning streaks, although how much this should matter would depend on the particular specification of voting behavior. Table 6 shows that to be the case in some instances. While teams with long winning streaks 
do not benefit more from a close loss, there is a slight benefit from losing to a strong opponent given a longer winning streak. The largest positive effect is for losing late in the season. Teams who manage to string together a number of consecutive wins receive the largest benefit to losing late.

As a last check, we should relax the assumption that each week of each season is a separate, independent observation. That obviously cannot be true. For example, there may be years in which pollsters act in a way that is different from other years, or teams that are perennially over-ranked or under-ranked, or weeks of the season that become "shakedown Saturdays" where the prominent teams of the season separate themselves from the rest of the pack. Also, many teams in the data play one another, such that a win for one team will be a loss for another. While this is not a double counting, per se (for example, each team will have its own point change, opponent strength, etc.), it does imply that the outcomes for some teams will be highly correlated when they play one another. I deal with these possibilities in three ways. First, I estimate the regression with team and season effects. That is, Michigan may be a perennially over-ranked team (a team effect), and 1987 could have been a year of low rankings due to significant disagreement amongst the pollsters (a season effect). Secondly, I interact team and season effects to create team-season effects, where now each team, season, and team-season have their own fixed effects. Lastly, I cluster the standard errors by season (to adjust for correlation by season), by team (to adjust for correlation of team quality/performance over successive weeks and seasons), and by week of season (to adjust for the correlation when one team in the data plays another) to see if the result is robust to these concerns. ${ }^{47}$ Table 7 presents the results. The addition of the team and season effects changes some of the results. For example, blowout wins do confer an advantage in this specification. ${ }^{48}$ Similarly, the benefits of close losses cease to be statistically significant once clustered standard errors are included. The results for blowout losses and opponent strength remain, as

\footnotetext{
${ }^{47}$ In the terminology of Bertrand, Duflo, and Mullainathan (2004), this type of clustering produces an arbitrary variance covariance matrix which is consistent in the presence of any type of correlation within the cluster over time.

${ }^{48}$ As we will see later this result is not robust to alternative specifications.
} 
do the results for late losses. Overall, the results are not especially sensitive to the inclusion of team or season effects, but others are sensitive to clustered errors.

\section{Specification Checks A. Checks for Timing of Losses}

The result that teams actually benefit by losing later in the season, relative to those that lose earlier, can be checked in two ways. First, Table 8 gives the summary statistics by different definitions of "late in the season." In the results presented earlier, late in the season was defined as the tenth week or later, and in Table $8 \mathrm{I}$ use the $8^{\text {th }}, 9^{\text {th }}, 10^{\text {th }}$, and $11^{\text {th }}$ weeks as the starting dates for late in the season. Table 8 shows that, relative to the season overall, later games are not more or less likely to result in victory or defeat, and the tenth and later weeks are not unique. Scores of teams and their opponents, the likelihood of a blowout or close win are the same as for the season overall. If I define late in the season as the $8^{\text {th }}$ week or later, the summary measures are the same as if I define late in the season as the $11^{\text {th }}$ week or later. To confirm the robustness of the result to the alternative definitions, I replicated the regression of Table 3 for these alternative definitions of late in the season. Table 9 shows the results. While the result remains, there is a change in the magnitude, and the value of losing later in the season is anywhere from $10 \%$ to $18 \%$ of the value of losing, depending on the specification. Recalling the discussion of the conventional wisdom, this result is still surprising-the conventional wisdom supposed that the result should be negative and large, and Table 9 confirms that the result is large and positive under these alternative definitions of late weeks of the season.

\section{B. Checks for Opponent Strength}

How can we be sure that the results for opponent strength truly reflect a lack of attention to the quality of the opponent? One check would be to use alternative definitions of opponent strength. When 
I replicated the results of Table 3 with opponent strength defined as wins minus losses at the time the game was played the results were unchanged - this is likely due to the fact that the current win/loss record is highly correlated with the season win/loss record, particularly after the first few games of the season are played, and as such is not a strong check of the results. To see if teams were rewarded for playing (and defeating) strong opponents I replicated the results of Table 3 using only the sample of teams that played another ranked team. I do this check because it could well be that AP voters do not factor strength of the opponent, but they may factor "quality wins," victories over teams that are highly ranked, which would be a select number of strong opponents. Table 10 shows the results. Here, I include the rank of the opponent inverted, so that a team ranked tenth receives an "opponent rank" measure of $1 / 10$ and a team ranked second receives a value of $1 / 2$. Winning against a ranked opponent confers no advantage, and losing against a ranked opponent confers no advantage. Even including the strength of the opponent here does not improve the results. One problem with the use of inverted rank is that it is not possible to interpret the effect in a straightforward manner. To overcome this difficulty I replicated the results of Table 10 using the log of the inverted rank and the results were similar. For example, in a specification that was similar to column I of Table 10 the coefficient on winning * the logged inverted rank was -18.18 [-0.40] and the coefficient on losing * the logged inverted rank was $33.42[-0.74]$ ( $\mathrm{t}$ statistics in brackets). Also, when I use the measure of strength of opponent and restrict the sample to ranked teams, opponent's strength has no effect. ${ }^{49}$

\section{Checks for Margin of Victory}

In the specifications presented so far margin of victory was a dichotomous measure that indicated a close or wide point differential. Controlling for team and season effects seemed to suggest

\footnotetext{
${ }^{49}$ In regression similar to those of Table 10 where I restrict the sample to be of ranked teams playing ranked teams (and where I do not include measures of the opponent's rank) the coefficient on opponent strength is 1.64 [0.14], the
} 
that blowing teams out did result in some style points, although other specifications did not. Another way to see if margin of victory matters is to use the actual point differential in the specification rather than dichotomous indicators. Table 11 shows the results. Column I shows that the point differential has no effect, and that defeating a strong opponent by a wide margin may actually cost a team points. Recall, however, that losing by wide margins appeared to be particularly negative, so there may be a difference for winning margins $(M>0)$ and losing margins $(M<0)$. I account for this by separating the effects for winning margins of victory and losing margins of victory. Column III-VI shows the results. In all of the specifications, margin of victory does not have a statistically significant relationship with point differentials, confirming the results of Table 3. Interacting margin of victory (defeat) with opponent strength does result in a statistically significant relationship. Losing by wide margins to strong opponents hurts (note that losing differential is a negative), which is consistent with the results for blowout losses discussed earlier. Curiously, defeating strong opponents by wide margins cost points as well. For example, if a team defeated a $8-3$ record team by 20 points they would actually lose close to 20 points in the subsequent poll. Conversely, losing to the same team by the same margin would result in a 50 fewer points in the next poll. At the extreme, one could say that the results of Table 11 are consistent with the fact that teams should win by large margins $(M>>0)$ against weak opponents (opponent strength $<<0$ ), but the results also imply that it is better, in terms of points, to lose by a large margin $(\mathrm{M}<<0)$ to a weak opponent (opponent strength $<<0)$. For example, defeating a 3-8 record opponent by 20 points results in $(M=20$, opponent strength $=-5)$ results in a point gain of 20 points. However, losing to a 3-8 opponent by 20 points $(M=-20$, opponent strength $=-5)$ results in a gain of more than 50 points. These specifications suggest that the combination of margin of victory with opponent strength may matter in curious ways that we might not have realized previously, but margin of victory itself is not substantially related to point changes in the AP poll.

coefficient on winning * opponent strength is 0.42 [0.04], and the coefficient on losing * opponent strength is 12.89 


\section{Discussion and Conclusion}

The conventional wisdom offered by pundits regarding college football has little empirical support-and in some instances is exactly the opposite of what "everyone knows" is true. Instead of teams suffering more for losing later in the season, a late season loss actually cushions the blow. Rather than being rewarded for defeating strong opponents, AP voters seem not to pay attention to the strength of a defeated opponent. Similarly, margin of victory seems to matter little in how AP voters choose to reward a team's performance. The results presented in this paper showed that the failure of the conventional wisdom is robust to a number of specification checks and alternative definitions.

The lingering question is how such conventional wisdom persists despite the strong evidence to the contrary. One feature of the pieces of conventional wisdom outlined above is their insistence on the use of anecdote to establish their claims. For example, here is what one sportswriter said about the importance of margin of victory

Yes, sportsmanship matters, and there's no room in some voters' minds for rubbing it in. Still, it's important to win by a comfortable margin if you can. Just ask Penn State. In 1994, the Nittany Lions roared into Bloomington, Ind., with a 7-0 record for a date with Indiana. Penn State was ranked No. 1 ranking and had an eye on the national championship. The Nittany Lions got off to a dominating start and built a comfy lead, but Indiana notched several second-half scores to narrow the final margin to 35-29, making Penn State's game against an unranked foe look more competitive than it was. As a result, unimpressed voters knocked Penn State to No. 2, where it sat idly by and watched Nebraska win the national championship. ${ }^{50}$

This anecdote is used to claim that the general strategy of winning by wide margins is rewarded, although I find no evidence that that is true. Similar anecdotal-based claims about other features of conventional wisdom tested here are common. Note also that this claim embodies more than one piece of conventional wisdom-Indiana was an unranked opponent, and voters took into account not only margin of victory but how strong the opponent was. This reflects, in my view, the standard practice of

[1.08]— $\mathrm{t}$ statistics in brackets. 
inferring, incorrectly, from small samples. Indeed, the conventional claims made here could be classified, in a somewhat loose way, as beliefs by those who draw inferences from the law of small numbers. Rabin (2002) documents the fact that agents may, if the distribution of signals is unknown, over infer from the present signal. In the case of college football, one would derive their beliefs based on a few salient outcomes and then claim that those outcomes (which may themselves be the result of an accurately described phenomena) apply more generally. In other words, it may well be true that Penn State's drop in the polls in the 1994 season was the result of voters looking negatively upon their margin of victory over Indiana, but it is a far leap to conclude that it matters for ranked teams in general.

This leads to a second way in which the conventional wisdom could be related to belief formation-salience. In most claims in support of conventional wisdom, stories from the past are usually focused on teams that were very highly ranked, and yet the claims of conventional wisdom are quite general. It is difficult to say why and how this conventional wisdom develops, but these two explanations are consistent with its widespread persistence in college football. Perhaps due to its rich and colorful history, college football gives rise to stories and anecdotes that become "truths" without any careful consideration.

Beyond the conventional wisdom tests themselves, these results also inform some current debates in college football. While the BCS system (begun in 1998) is designed to produce a national championship game where the \#1 and \#2 ranked teams play against one another, the system has not avoided controversy. As such, proponents of a playoff have argued for some time that a 4, 8, or 16 team playoff is needed to "truly" determine the national champion. If any system were to determine the final 4 or 8 teams who would play for a championship, it is likely to be similar to the current BCS formula, and only different to the extent that it incorporates more teams in a playoff system. Since such a system is likely to use polls to rank the teams that would qualify for the playoff, the results here should

${ }^{50}$ Dienart (2002) 
be noted if it is believed that they may inappropriately help or hurt some teams. For example, in the final regular season poll for the 2006 season, the point difference between the team ranked \#4 (LSU) and \#5 (Louisville) was 32 points, and the difference between \#4 (Ohio State) and \#5 (Notre Dame) in 2005 was 48 points. As such, the results here, where losing late in the season can save upwards of 50 points, would have implications for who would be allowed to play for a national championship as long as rankings were based on polls. The stakes of these cutoffs are potentially quite high. For example, appearing in a BCS bowl nets a team more than $\$ 15$ million, while the next largest bowl payout is less than $\$ 5$ million.

In the end, shedding light on the conventional wisdom of college football has several benefits. First, it gives us an opportunity to test simple, primitive models of voting behavior that are grounded in conventional wisdom. Second, it provides strong evidence that our received wisdom about voting is often wrong, even in trivial matters such as the ranking of amateur football teams and the determination of a mythical champion. Third, these results may help us to devise a system of ranking teams and choosing a champion, where the stakes, for individual universities, can be quite high. Fourth, they allow us to see relationships in the voting behavior of AP pollsters that was previously undetected, and this may itself induce changes in voting procedures or policies. All of this however, is simply a side show to the main event; the actual games played around the country are the true heart and soul of college football and the primary reason for its enduring popularity.

Everybody knows that. 


\section{References}

Barnhart, Tony (1998) "Inside Colleges: Some Coaches Still Absentees in Polls" Atlanta Journal Constitution Aug. 9, 1998.

Barra, Allen (2001) "Bring Back the Arbitrary College Football Polls!” Slate Magazine http://www.salon.com/news/sports/col/barra/2001/11/29/polls/ (accessed Oct. 12, 2007)

Bertrand, Marianne, Esther Duflo and Sendhil Mullainathan (2004) "How Much Should We Trust Differences-in-Differences Estimates?" Quarterly Journal of Economics 119: 249-275.

Buchanan, James and Yong Yoon (2006) "All Voting is Strategic" Public Choice 127: 159-167.

Caldwell, David (2002) “College Football: The Record's of Opponents Help Life Idle Oklahoma” New York Times Oct. 29, 2002.

Callaghan, Thomas, Peter J. Mucha, and Mason A. Porter (2004) "The Bowl Championship Series: A Mathematical Review" Notices of the American Mathematical Society 51: 887-893.

Campbell, Noah D., Tammy M. Rodgers and Zachary Finney (2007) "Evidence of Television Exposure Effects in AP Top 25 College Football Rankings" Journal of Sports Economics 8: 425-434.

Caparell, Adam (2007) "2007 Schedule Planner: Week One” http://www.cstv.com/sports/mfootbl/stories/052407aab.html (accessed October 18, 2007)

Depken, Craig and Dennis Wilson (2006) "NCAA Enforcement and Competitive Balance in College Football” Southern Economic Journal 72: 826-845.

Dienhart, Tom (2002) "Winning Big Should Count for Something” The Sporting News June 24, 2002.

Drape, Joe (2002) “College Football: In Real Life, Victory Margin Matters” New York. Times, Oct. 3, 2002.

Fair, Ray C. and John F. Oster (2007) "College Football Rankings and Market Efficiency" Journal of Sports Economics 8: 3-18.

Fiutak, Pete (2007) "Ask CFN [College Football News]—Can A\&M Really be Great?” http://cfn.scout.com/2/684667.html (accessed October 23, 2007)

Fogel, Robert W. (1975) "The Limits of Quantitative Methods in History" American Historical Review 80: 329-350.

Frechette, Guillaume, Alvin Roth and M. Utku Unver (2007) "Unraveling Yields Inefficient Matchings: Evidence from Post-Season College Football Bowls" Forthcoming, RAND Journal of Economics.

Goff, Brian (1996) "An Assessment of Path Dependence in Collective Decisions: Evidence from Football Polls" Applied Economics 28: 291-297.

Langllet, George (2003) "The Relationship Between Recruiting and Team Performance in Division 1A College Football." Journal of Sports Economics 4: 240-245.

Lebovic, James H. and Lee Sigelman (2001) "The Forecasting Accuracy and Determinants of Football Rankings” International Journal of Forecasting 17: 105-120.

Lowenstein, George, Ted O’Donoghue and Matthew Rabin (2003) "Projection Bias in Predicting Future Utility" Quarterly Journal of Economics 118: 1209-1248.

MacCambridge, Michael, ed., (2005) ESPN College Football Encyclopedia: The Complete History of the Game. New York: ESPN Books.

Mandel, Stewart (2005) “The Real BCS Controversy: Want Evidence of Bias? Just Look at Coaches' Votes" Sports Illustrated Online http://sportsillustrated.cnn.com/2005/writers/stewart mandel/12/07/mailbag/index.html (accessed October 27, 2007).

Mandel, Stewart (2007) "No.1...for now: South Florida Earns Top Spot After LSU, Cal go Down." Sports Illustrated Online http://sportsillustrated.cnn.com/2007/writers/stewart mandel/10/16/power.rankings8/index. $\underline{\mathrm{html}}$ (accessed October 20, 2007) 
Paul, Rodney J., Amdrew Weinbach and Patrick Coate (2007) "Expectations and Voting in the NCAA Football Polls (The Wisdom of Point Spreads)" Journal of Sports Economics 8: 412-424.

Rabin, Matthew (2002) "Inference by Believers in the Law of Small Numbers" Quarterly Journal of Economics 117: 817-869.

Rabin, Matthew and Joel Schrag (1999) "First Impressions Matter: A Model of Confirmatory Bias" Quarterly Journal of Economics 114: 37-82.

Reback, Jared (2007) "Puling Rank: Hoe the College Football Polls Should Work." http://www.bleacherreport.com/articles/2849-College FootballPulling Rank How the Polls Should Work-141007 (accessed October 22, 2007)

Romer, David (2006) “Do Firms Maximize? Evidence from Professional Football” Journal of Political Economy 114: 340-365.

Russo, Ralph D. (2007) “What is Proper Blowout Etiquette?” AP Wire, Sept. 19, 2007

Sutter, Daniel and Stephen Winkler (2003) "NCAA Scholarship Limits and Competitive Balance in College Football” Journal of Sports Economics 4: 3-18.

Tamanaha, John (2007) "Now Entering the 'Knockout Stages"' MSNBC Report http://extrapoints.msnbc.msn.com/archive/2007/10/14/410366.aspx (accessed October 20, 2007)

Wieberg, Steve (2005) "New Harris Poll to Replace AP in BCS." USA Today July 11, 2005. 


\section{Data Appendix}

The data used in this paper was collected from two sources. The ESPN College Football Encyclopedia (MacCambridge 2005) was used to obtain all information except AP poll points, which were obtained from the website www.soonerstats.com, which is the website that the editor of the ESPN College Football Encyclopedia used for the historical AP poll progressions. ${ }^{51}$ The Encyclopedia lists the date of the game, the location of the game, the opponent, the score, and the ranking of the team and the opponent before and after the game. Cross-checks in the Encyclopedia allowed us to gather the win/loss record for each opponent at the time of the game and for that season. For the analysis, each game of each season for all 25 teams was recorded, whether they were ranked or unranked at the time of the game. In addition to this raw data from the Encyclopedia and the points from the AP poll, the following variables were created:

-- "Close Win/Loss" is defined as a margin of victory of 3 points or less. Ties are listed separately and are not included.

-- "Blowout Win/Loss" is a margin of victory of more than 17 points (this means winning by more than two touchdowns, two point-after-touchdowns, and one field goal).

-- "Opponent Strength (Season)" is the number of victories minus the number of losses for an opponent that season.

-- "Opponent Strength (Game)" is the number of victories minus the number of losses for an opponent at the time that they played the game in the data.

-- "Week of Season" is the poll-week of the season. Since the preseason poll is a ranking of teams before any games are actually played, I note this as the zero week of the season.

Changes in points and rankings are taken as week to week changes (e.g., the points/ranking from week three minus the points/ranking from week two) and the covariates in all models use the actual week of the event (e.g., the change from week two to three is regressed on the game characteristics of the game played between the second and third week rankings). As there are more weeks of the season than games played by any individual team, there are "bye" weeks in which a team in inactive and their rank may change. Since these weeks contain no information about a given team (since they have not played an opponent in the interim) they are not used in this analysis. However, it must be noted that if their ranking changed this would be reflected in the data. For example, suppose a team was ranked 21 st in the fourth week of the season, and did not play in the fifth week of the season, but changed ranking to 19 in the fifth week. In the sixth week the team played and their rank changed to 18. The change from the third to fourth week is recorded here, as is the change in the fifth to sixth week. When I ran specifications with the teams as "tied" for inactive weeks (the fourth to fifth in this example) the results were unchanged.

Data was collected between March 2005 and December 2006. The raw data was audited for accuracy using the following algorithm. First, 3 seasons were randomly selected and these seasons were re-checked for each team. Then, three weeks of seasons were randomly selected and these were checked for each team. Finally, three teams were selected and their results re-checked. In any instance, if more than $5 \%$ of the entries checked had to be changed for any reason that team's entire entry was redone. The auditing took place from January 2007 to June 2007.

${ }^{51}$ The AP polls are for each week are listed at http://www.appollarchive.com/football/index.cfm 
The largest changes in the poll is that beginning in 199025 teams were ranked instead of 20, as had been the case from before 1990. In the data presented here, I weighted all 1980 to 1989 AP points by $(25 / 20)$, which transforms the points as if there were 25 teams to be ranked in those polls. This preserves the original ranking while at the same time awarding "contemporary" point totals. Similarly, in different years there are different numbers of voters in the AP poll. While this difference in levels is somewhat dealt with by the inclusion of season specific effects, I also standardized the point totals to control for differences in the number of AP voters.

There are five additional checks that should be performed on the data. The first is a check that acknowledges the changes in the AP poll, which until 1990 only ranked 20 teams. A check, however, would be to throw out all rankings from 20-25 for all years after 1990. Appendix Table A shows the results, which are robust to the exclusion of all teams ranked 21-25. Similarly, the data here only records information on teams that are ranked both before and after the game. Teams can, and do, place themselves onto the rankings and also drop from the top 25 throughout the course of a season. Ideally, one would like to construct an imputed point total for each team, but that is not possible since an invented point total will not necessarily be consistent across all years. To deal with this possibility, I imputed a rank of 30 for any team that was unranked before or after a game. Appendix Table B shows the results, which regress the changes in rank on the game characteristics. The results are robust, at least for the ranking regressions, when a teams former or current rank is imputed. It is difficult to know how to interpret the effect of opponent strength in these regressions, however, because of the use of imputed rankings. Bowl games and championship games may be the driving factors behind the results as they usually feature an inordinate number of high quality matchups. I exclude Bowl Games and Conference Championship games from the data in Appendix Table C. The results are not sensitive the exclusion of these teams. Fourth, to deal with the concern that the results are driven by highly ranked teams, I excluded all teams ranked 1-5 from the regressions in Appendix Table D. As the Table show, the results are robust to their exclusion. Last, Appendix Table E replicates the regression of Column VI of Table 3 and includes week of the season in the specification. The central results are robust to this alternative specification. 
Table 1

List the College Football Teams in Sample

$\begin{array}{ll}\text { Alabama } & \text { Miami (Florida) } \\ \text { Arkansas } & \text { Michigan } \\ \text { Auburn } & \text { Nebraska } \\ \text { Boston College (BC) } & \text { Notre Dame } \\ \text { Brigham Young (BYU) } & \text { Ohio State } \\ \text { California (Cal) } & \text { Oklahoma } \\ \text { California, Los Angeles (UCLA) } & \text { Pennsylvania State (Penn State) } \\ \text { Colorado } & \text { Southern California (USC) } \\ \text { Florida } & \text { Stanford } \\ \text { Florida State } & \text { Tennessee } \\ \text { Georgia } & \text { Texas } \\ \text { Iowa } & \text { Texas Agricultural and Mechanical (Texas A\&M) }\end{array}$

Louisiana State (LSU)

Note: The data used in the paper contains each game played by the teams listed above from the 1980-1981 season to the 2004-2005 season. 
Table 2

Summary Statistics

\begin{tabular}{|c|c|c|c|c|c|}
\hline \multicolumn{6}{|c|}{ Ranking Measures } \\
\hline Variable & $\mathrm{N}$ & Mean & Std. Dev. & Min & Max \\
\hline Points Change & 4199 & 1.83 & 186.94 & -1007 & 910 \\
\hline Rank Change & 4286 & 0.00 & 3.16 & -12 & 16 \\
\hline Points of Team Before Game & 4483 & 871.98 & 447.44 & 36 & 1850 \\
\hline Points of Team After Game & 4463 & 870.67 & 449.60 & 3 & 1850 \\
\hline Rank of Team Before Game & 4483 & 10.44 & 6.60 & 1 & 25 \\
\hline Rank of Team After Game & 4463 & 10.35 & 6.56 & 1 & 25 \\
\hline \multicolumn{6}{|c|}{ Game Characteristics } \\
\hline Variable & $\mathrm{N}$ & Mean & Std. Dev. & Min & $\operatorname{Max}$ \\
\hline Win & 7502 & 0.75 & 0.43 & 0 & 1 \\
\hline Loss & 7502 & 0.24 & 0.43 & 0 & 1 \\
\hline Tie & 7502 & 0.01 & 0.12 & 0 & 1 \\
\hline Score of Team & 7502 & 28.20 & 14.65 & 0 & 86 \\
\hline Score of Opponent & 7502 & 19.23 & 12.10 & 0 & 82 \\
\hline Margin of Victory & 7502 & 8.97 & 20.77 & -77 & 81 \\
\hline Blowout Win & 7502 & 0.37 & 0.48 & 0 & 1 \\
\hline Blowout Loss & 7502 & 0.12 & 0.32 & 0 & 1 \\
\hline Close Win & 7502 & 0.10 & 0.29 & 0 & 1 \\
\hline Close Loss & 7502 & 0.08 & 0.27 & 0 & 1 \\
\hline
\end{tabular}

Author's Calculations. See data appendix for definitions. 
Table 3

Change in AP Points on Between Rank Game Characteristics

\begin{tabular}{|c|c|c|c|c|c|c|}
\hline & $\mathrm{I}$ & II & III & IV & $\mathrm{V}$ & VI \\
\hline \multirow[t]{2}{*}{ Win } & $174.7 * * *$ & $124.1^{* * *}$ & $193.9 * * *$ & $191.1 * * *$ & $193.7^{* * *}$ & $192.8^{* * *}$ \\
\hline & {$[9.64]$} & [2.69] & [2.96] & {$[2.79]$} & [2.83] & {$[2.81]$} \\
\hline \multirow[t]{2}{*}{ Lose } & $-169.3 * * *$ & $-133.2^{* * *}$ & $-221.0 * * *$ & $-274.2 * * *$ & $-292.0 * * *$ & $-289.3^{* * *}$ \\
\hline & {$[-9.09]$} & {$[-2.83]$} & {$[-3.29]$} & {$[-3.88]$} & {$[-4.14]$} & {$[-4.08]$} \\
\hline \multirow[t]{2}{*}{ Close Win } & & & -9.002 & -7.943 & -8.091 & -8.352 \\
\hline & & & {$[-0.90]$} & {$[-0.79]$} & {$[-0.81]$} & {$[-0.84]$} \\
\hline \multirow[t]{2}{*}{ Close Loss } & & & $24.04 *$ & $28.95^{* *}$ & $30.06^{* *}$ & $29.64 * *$ \\
\hline & & & {$[1.71]$} & {$[2.06]$} & {$[2.14]$} & [2.11] \\
\hline \multirow[t]{2}{*}{ Blowout Win } & & & $11.26^{*}$ & 8.654 & 8.472 & 8.835 \\
\hline & & & {$[1.76]$} & {$[1.35]$} & [1.32] & {$[1.25]$} \\
\hline \multirow[t]{2}{*}{ Blowout Loss } & & & $-42.30 * * *$ & $-50.43^{* * *}$ & $-49.50 * * *$ & $-46.89 * * *$ \\
\hline & & & {$[-3.13]$} & {$[-3.71]$} & {$[-3.65]$} & {$[-3.05]$} \\
\hline \multirow[t]{2}{*}{ Opponent Strength } & & & $5.161 * * *$ & 2.448 & 2.448 & 2.448 \\
\hline & & & {$[9.24]$} & {$[0.52]$} & {$[0.52]$} & {$[0.52]$} \\
\hline \multirow[t]{2}{*}{ Win * Opponent Strength } & & & & 1.647 & 1.676 & 1.87 \\
\hline & & & & {$[0.35]$} & {$[0.36]$} & {$[0.40]$} \\
\hline \multirow[t]{2}{*}{ Lose $*$ Opponent Strength } & & & & $9.554^{*}$ & $9.082^{*}$ & $8.350^{*}$ \\
\hline & & & & [1.94] & [1.85] & {$[1.70]$} \\
\hline \multirow[t]{2}{*}{ Win Late in Season? } & & & & & -4.335 & -5.092 \\
\hline & & & & & {$[-0.67]$} & {$[-0.53]$} \\
\hline \multirow[t]{2}{*}{ Lose Late in Season? } & & & & & $48.89 * * *$ & $51.18^{* * *}$ \\
\hline & & & & & [3.92] & [3.59] \\
\hline Win/Loss * Home /Away & & $\mathrm{X}$ & $\mathrm{X}$ & $\mathrm{X}$ & $\mathrm{X}$ & $\mathrm{X}$ \\
\hline Close Win/Loss *Home/Away & & & & & & $\mathrm{X}$ \\
\hline Blowout Win/Loss * Home/Away * Late & & & & & & $\mathrm{X}$ \\
\hline Observations & 5578 & 5578 & 3846 & 3846 & 3846 & 3846 \\
\hline R-squared & 0.44 & 0.46 & 0.49 & 0.5 & 0.5 & 0.5 \\
\hline
\end{tabular}

T statistics in brackets $\left[{ }^{* * *} \mathrm{p}<.01,{ }^{* *} \mathrm{p}<.05,{ }^{*} \mathrm{p}<0.1\right]$

Each column is a regression on the change in points in the AP poll on game characteristics. Late in Season is defined as being after the tenth (10) poll week of the season. Opponent strength is defined as the number of wins minus the number of losses of the opponent for that season. Blowout is margin of victory $>14$, close is margin of victory $<3$. See the data appendix for further description. 
Table 4

Game Characteristc Interactions

\begin{tabular}{|c|c|c|c|c|c|c|}
\hline & $\mathrm{I}$ & II & III & IV & V & VI \\
\hline \multirow[t]{2}{*}{ Win Late in Season? } & -7.205 & -2.998 & -12.68 & -2.998 & -2.998 & -1.276 \\
\hline & {$[-0.67]$} & {$[-0.28]$} & {$[-1.13]$} & {$[-0.47]$} & {$[-0.40]$} & {$[-0.15]$} \\
\hline \multirow[t]{2}{*}{ Lose Late in Season? } & $57.67 * * *$ & $61.21 * * *$ & $60.64^{* * *}$ & $61.21 * * *$ & $61.21 * * *$ & $61.03^{* * *}$ \\
\hline & {$[3.54]$} & {$[3.77]$} & {$[3.52]$} & {$[3.24]$} & {$[3.12]$} & {$[3.35]$} \\
\hline \multirow[t]{2}{*}{ Win Late in Blowout? (Home) } & 6.259 & 6.567 & 7.48 & 6.567 & 6.567 & 5.053 \\
\hline & {$[0.41]$} & {$[0.43]$} & {$[0.47]$} & {$[0.51]$} & {$[0.44]$} & {$[0.43]$} \\
\hline \multirow[t]{2}{*}{ Lose Late in Blowout? (Home) } & -101.3 & -112.9 & -110.1 & -112.9 & -112.9 & $-112.3^{* *}$ \\
\hline & {$[-1.29]$} & {$[-1.45]$} & {$[-1.34]$} & {$[-1.42]$} & {$[-1.45]$} & {$[-2.23]$} \\
\hline \multirow[t]{2}{*}{ Win Late in Blowout? (Away) } & -9.055 & -11.26 & -16.22 & -11.26 & -11.26 & -12.67 \\
\hline & {$[-0.50]$} & {$[-0.62]$} & {$[-0.85]$} & {$[-0.93]$} & {$[-0.89]$} & {$[-1.11]$} \\
\hline \multirow[t]{2}{*}{ Lose Late in Blowout? (Away) } & -99.04 & -94.91 & $-128.3^{*}$ & -94.91 & -94.91 & -94.3 \\
\hline & {$[-1.60]$} & {$[-1.53]$} & {$[-1.93]$} & {$[-1.21]$} & {$[-1.37]$} & {$[-1.40]$} \\
\hline \multirow[t]{2}{*}{ Win Late in Blowout? (Home) * Opp Str } & -0.309 & -0.675 & -1.482 & -0.675 & -0.675 & -0.732 \\
\hline & {$[-0.14]$} & {$[-0.31]$} & {$[-0.64]$} & {$[-0.36]$} & {$[-0.39]$} & {$[-0.49]$} \\
\hline \multirow[t]{2}{*}{ Lose Late in Blowout? (Home) * Opp Str } & $18.51 *$ & $19.25 *$ & $20.86^{*}$ & $19.25^{* * *}$ & $19.25^{*}$ & $19.23 * * *$ \\
\hline & {$[1.70]$} & {$[1.78]$} & [1.83] & [2.88] & {$[1.75]$} & {$[3.20]$} \\
\hline \multirow[t]{2}{*}{ Win Late in Blowout? (Away) *Opp Str } & -3.485 & -3.919 & -4.435 & $-3.919 * * *$ & $-3.919 * *$ & $-3.951 * * *$ \\
\hline & {$[-1.27]$} & {$[-1.43]$} & {$[-1.55]$} & {$[-3.05]$} & {$[-2.55]$} & {$[-5.26]$} \\
\hline \multirow[t]{2}{*}{ Lose Late in Blowout? (Away) * Opp Str } & 11.62 & 10.81 & 13.51 & 10.81 & 10.81 & 10.77 \\
\hline & {$[1.44]$} & {$[1.34]$} & {$[1.55]$} & [1.09] & {$[1.10]$} & {$[1.07]$} \\
\hline \multirow[t]{2}{*}{ Win Late Close? (Home) } & 3.518 & 7.83 & 20.13 & 7.83 & 7.83 & 4.714 \\
\hline & {$[0.10]$} & {$[0.22]$} & {$[0.55]$} & {$[0.46]$} & [0.39] & {$[0.21]$} \\
\hline \multirow[t]{2}{*}{ Lose Late Close? (Home) } & -80.13 & -66.65 & -68.57 & -66.65 & -66.65 & -65.17 \\
\hline & {$[-1.50]$} & {$[-1.25]$} & {$[-1.23]$} & {$[-1.23]$} & {$[-1.39]$} & {$[-1.06]$} \\
\hline \multirow[t]{2}{*}{ Win Late Close? (Away) } & 20.82 & 20.57 & 34.18 & 20.57 & 20.57 & 17.75 \\
\hline & {$[0.74]$} & {$[0.73]$} & {$[1.15]$} & {$[1.27]$} & {$[1.26]$} & {$[1.32]$} \\
\hline \multirow[t]{2}{*}{ Lose Late Close? (Away) } & $-125.7 * *$ & $-139.4^{* *}$ & $-194.3 * * *$ & $-139.4 * *$ & $-139.4^{* *}$ & $-139.2 * * *$ \\
\hline & {$[-2.00]$} & {$[-2.22]$} & {$[-2.91]$} & {$[-2.70]$} & {$[-2.23]$} & {$[-3.57]$} \\
\hline \multirow[t]{2}{*}{ Win Late Close? (Home) * Opp Strength } & -7.079 & -6.738 & -7.94 & -6.738 & -6.738 & -6.757 \\
\hline & {$[-1.04]$} & {$[-1.00]$} & {$[-1.13]$} & {$[-0.92]$} & {$[-0.86]$} & {$[-0.67]$} \\
\hline \multirow[t]{2}{*}{ Lose Late Close? (Home) * Opp Strength } & $13.73^{*}$ & 12.33 & 13.03 & $12.33^{*}$ & $12.33^{* *}$ & $12.25^{* *}$ \\
\hline & {$[1.77]$} & {$[1.60]$} & {$[1.61]$} & {$[1.75]$} & {$[2.16]$} & {$[2.44]$} \\
\hline \multirow[t]{2}{*}{ Win Late Close? (Away) * Opp Strength } & 5.251 & 4.662 & 3.52 & 4.662 & 4.662 & $4.675^{* *}$ \\
\hline & {$[0.95]$} & {$[0.84]$} & {$[0.60]$} & [1.28] & {$[1.34]$} & {$[2.14]$} \\
\hline \multirow[t]{2}{*}{ Lose Late Close? (Away) * Opp Strength } & $16.53 *$ & $18.47^{* *}$ & $26.89 * * *$ & $18.47^{* *}$ & $18.47^{* *}$ & $18.54 * * *$ \\
\hline & [1.81] & [2.03] & [2.79] & [2.28] & [2.27] & [3.38] \\
\hline Season Effects, Team Effects, & & $\mathrm{X}$ & $\mathrm{X}$ & $\mathrm{X}$ & $\mathrm{X}$ & $\mathrm{X}$ \\
\hline \multicolumn{2}{|l|}{ Seaon $*$ Team Effects } & & $\mathrm{X}$ & $\mathrm{X}$ & $\mathrm{X}$ & $\mathrm{X}$ \\
\hline \multicolumn{2}{|l|}{ Team Cluster } & & & $\mathrm{X}$ & & \\
\hline \multicolumn{2}{|l|}{ Season Cluster } & & & & $\mathrm{X}$ & \\
\hline \multicolumn{2}{|l|}{ Week of Season Cluster } & & & & & $\mathrm{X}$ \\
\hline Observations & 3846 & 3846 & 3846 & 3846 & 3846 & 3845 \\
\hline R-squared & 0.5 & 0.52 & 0.57 & 0.52 & 0.52 & 0.52 \\
\hline
\end{tabular}

T statistics in brackets $\left[* * * \mathrm{p}<0.01,{ }^{* *} \mathrm{p}<0.05,{ }^{*} \mathrm{p}<0.1\right]$

These are selected coefficients for the change in AP poll points as a function of game characteristics. The regressions included win, loss, home, away, win/loss*home/away, close/blowout*win/loss*home/away, opponent strength, and win/loss*opponent strength.

See the data appendix for further details and variable definifions. 
Table 5

Validation Check: Results by Lagged Change in AP Points Results For Teams Who Had

Win

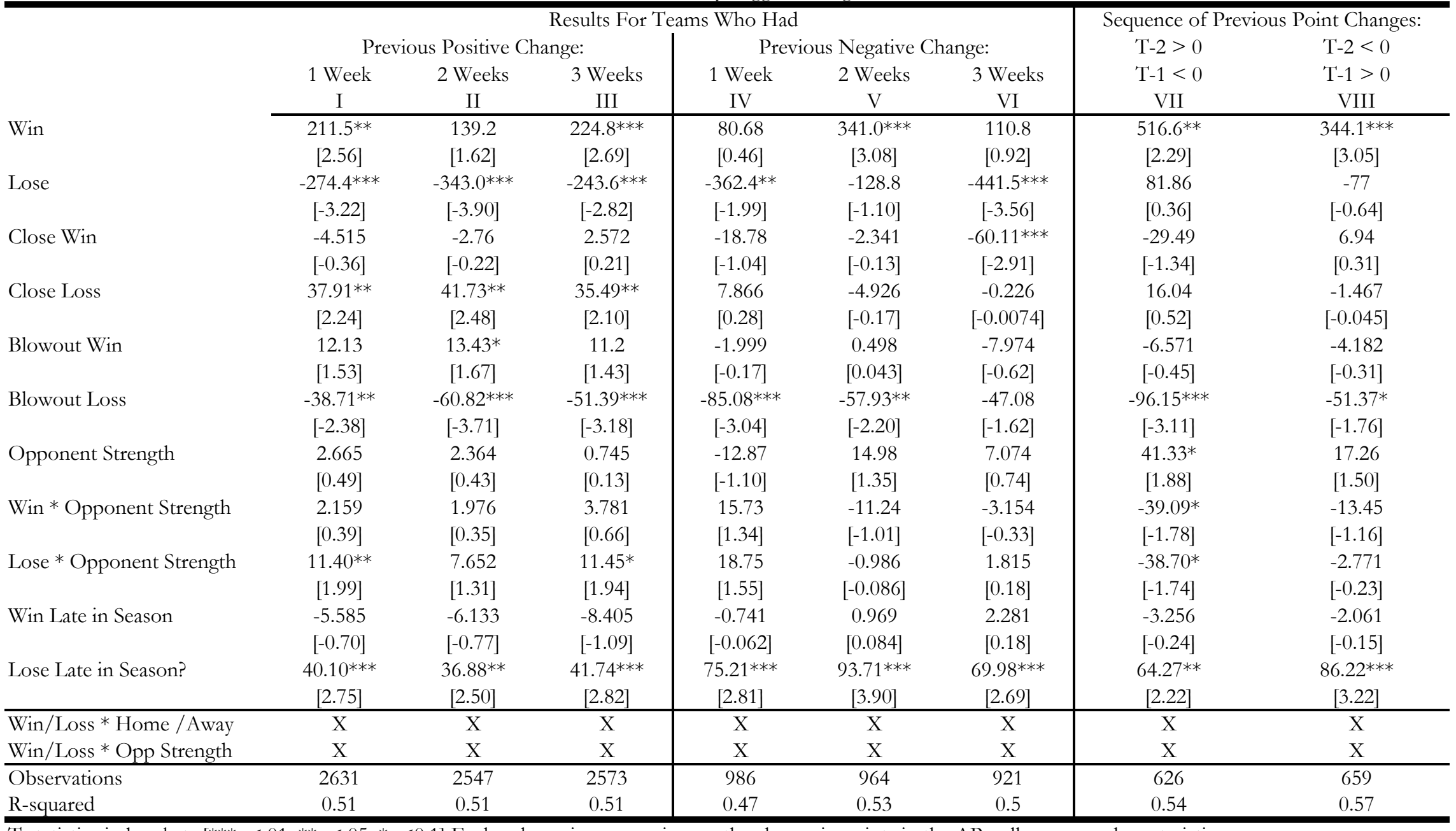

T statistics in brackets $\left[{ }^{* * *} \mathrm{p}<.01,{ }^{* *} \mathrm{p}<.05,{ }^{*} \mathrm{p}<0.1\right]$ Each column is a regression on the change in points in the AP poll on game characteristics.

Previous change is noted as a change given in the week noted only, sequence of previous change is conditioned on changes to the points in previous

weeks as noted.

See the data appendix for further description and variable definitions. 
Table 6

Validation Check: Results by Length of Winning Streak

\begin{tabular}{|c|c|c|c|c|c|c|}
\hline & \multicolumn{6}{|c|}{ Length of Winning Streak: } \\
\hline & $\begin{array}{c}6 \text { Games } \\
\mathrm{I}\end{array}$ & $\begin{array}{c}5 \text { Games } \\
\text { II }\end{array}$ & $\begin{array}{c}4 \text { Games } \\
\text { III }\end{array}$ & $\begin{array}{c}3 \text { Games } \\
\text { IV }\end{array}$ & $\begin{array}{c}2 \text { Games } \\
\mathrm{V}\end{array}$ & $\begin{array}{c}1 \text { Game } \\
\text { VI }\end{array}$ \\
\hline Win & $\begin{array}{l}87.76 \\
{[1.08]}\end{array}$ & $\begin{array}{l}92.61 \\
{[1.12]}\end{array}$ & $\begin{array}{l}122.3 \\
{[1.40]}\end{array}$ & $\begin{array}{c}142.9 * \\
{[1.65]}\end{array}$ & $\begin{array}{l}114.1 \\
{[1.48]}\end{array}$ & $\begin{array}{c}201.3 * * * \\
{[3.09]}\end{array}$ \\
\hline Lose & $\begin{array}{c}-412.8^{* * *} \\
{[-4.95]}\end{array}$ & $\begin{array}{c}-420.7 * * * \\
{[-4.95]}\end{array}$ & $\begin{array}{c}-363.6^{* * *} \\
{[-4.08]}\end{array}$ & $\begin{array}{c}-358.1 * * * \\
{[-4.07]}\end{array}$ & $\begin{array}{c}-413.2^{* * *} \\
{[-5.22]}\end{array}$ & $\begin{array}{c}-304.4^{* * *} \\
{[-4.53]}\end{array}$ \\
\hline Close Win & $\begin{array}{c}24.03^{*} \\
{[1.77]}\end{array}$ & $\begin{array}{l}18.87 \\
{[1.49]}\end{array}$ & $\begin{array}{l}11.04 \\
{[0.89]}\end{array}$ & $\begin{array}{l}7.651 \\
{[0.67]}\end{array}$ & $\begin{array}{l}-3.701 \\
{[-0.34]}\end{array}$ & $\begin{array}{l}-6.209 \\
{[-0.61]}\end{array}$ \\
\hline Close Loss & $\begin{array}{c}33.41 * \\
{[1.92]}\end{array}$ & $\begin{array}{c}32.00^{*} \\
{[1.92]}\end{array}$ & $\begin{array}{c}31.54^{*} \\
{[1.92]}\end{array}$ & $\begin{array}{c}39.04^{* *} \\
{[2.57]}\end{array}$ & $\begin{array}{c}36.65^{* *} \\
{[2.46]}\end{array}$ & $\begin{array}{c}33.47^{* *} \\
{[2.39]}\end{array}$ \\
\hline Blowout Win & $\begin{array}{l}7.403 \\
{[0.88]}\end{array}$ & $\begin{array}{l}10.34 \\
{[1.31]}\end{array}$ & $\begin{array}{l}12.01 \\
{[1.57]}\end{array}$ & $\begin{array}{l}10.31 \\
{[1.45]}\end{array}$ & $\begin{array}{c}8.46 \\
{[1.23]}\end{array}$ & $\begin{array}{c}7.2 \\
{[1.11]}\end{array}$ \\
\hline Blowout Loss & $\begin{array}{c}-92.28^{* * *} \\
{[-5.20]}\end{array}$ & $\begin{array}{c}-75.41 * * * \\
{[-4.55]}\end{array}$ & $\begin{array}{c}-74.74 * * * \\
{[-4.63]}\end{array}$ & $\begin{array}{c}-73.07 * * * \\
{[-4.84]}\end{array}$ & $\begin{array}{c}-47.58 * * * \\
{[-3.32]}\end{array}$ & $\begin{array}{c}-51.14 * * * \\
{[-3.77]}\end{array}$ \\
\hline Opponent Strength & $\begin{array}{l}-5.345 \\
{[-1.06]}\end{array}$ & $\begin{array}{l}-4.891 \\
{[-0.97]}\end{array}$ & $\begin{array}{c}-0.155 \\
{[-0.030]}\end{array}$ & $\begin{array}{l}1.503 \\
{[0.32]}\end{array}$ & $\begin{array}{l}-0.703 \\
{[-0.15]}\end{array}$ & $\begin{array}{l}1.812 \\
{[0.41]}\end{array}$ \\
\hline Win * Opponent Strength & $\begin{array}{l}7.702 \\
{[1.51]}\end{array}$ & $\begin{array}{l}7.755 \\
{[1.52]}\end{array}$ & $\begin{array}{l}3.604 \\
{[0.69]}\end{array}$ & $\begin{array}{c}1.69 \\
{[0.36]}\end{array}$ & $\begin{array}{l}4.474 \\
{[0.94]}\end{array}$ & $\begin{array}{l}2.016 \\
{[0.45]}\end{array}$ \\
\hline Lose * Opponent Strength & $\begin{array}{c}18.67 * * * \\
{[3.46]}\end{array}$ & $\begin{array}{c}17.86^{* * *} \\
{[3.34]}\end{array}$ & $\begin{array}{c}13.47 * * \\
{[2.48]}\end{array}$ & $\begin{array}{c}13.24 * * * \\
{[2.66]}\end{array}$ & $\begin{array}{c}14.08^{* * *} \\
{[2.82]}\end{array}$ & $\begin{array}{c}9.623^{* *} \\
{[2.04]}\end{array}$ \\
\hline Win Late in Season? & $\begin{array}{c}-22.60^{* * *} \\
{[-2.73]}\end{array}$ & $\begin{array}{c}-20.90 * * * \\
{[-2.65]}\end{array}$ & $\begin{array}{c}-24.02^{* * *} \\
{[-3.11]}\end{array}$ & $\begin{array}{c}-18.94 * * * \\
{[-2.61]}\end{array}$ & $\begin{array}{c}-16.36 * * \\
{[-2.33]}\end{array}$ & $\begin{array}{c}-12.62^{*} \\
{[-1.91]}\end{array}$ \\
\hline Lose Late in Season? & $\begin{array}{c}93.48^{* * *} \\
{[5.59]} \\
\end{array}$ & $\begin{array}{c}96.21^{* * *} \\
{[6.19]}\end{array}$ & $\begin{array}{c}92.16^{* * *} \\
{[6.19]} \\
\end{array}$ & $\begin{array}{c}52.50^{* * *} \\
{[3.84]} \\
\end{array}$ & $\begin{array}{c}42.98^{* * *} \\
{[3.27]}\end{array}$ & $\begin{array}{c}41.89 * * * \\
{[3.36]}\end{array}$ \\
\hline Win/Loss * Home /Away & $\mathrm{X}$ & $\mathrm{X}$ & $\mathrm{X}$ & $\mathrm{X}$ & $\mathrm{X}$ & $\mathrm{X}$ \\
\hline Win/Loss * Opp Strength & $\mathrm{X}$ & $\mathrm{X}$ & $\mathrm{X}$ & $\mathrm{X}$ & $\mathrm{X}$ & $\mathrm{X}$ \\
\hline $\begin{array}{l}\text { Observations } \\
\text { R-squared }\end{array}$ & $\begin{array}{l}1391 \\
0.64\end{array}$ & $\begin{array}{l}1699 \\
0.62\end{array}$ & $\begin{array}{c}2041 \\
0.58\end{array}$ & $\begin{array}{c}2426 \\
0.58\end{array}$ & $\begin{array}{c}2877 \\
0.55\end{array}$ & $\begin{array}{l}3367 \\
0.54\end{array}$ \\
\hline
\end{tabular}

T statistics in brackets [*** $\left.\mathrm{p}<.01,{ }^{* *} \mathrm{p}<.05,{ }^{*} \mathrm{p}<0.1\right]$

Only teams who had won the previous number of games listed are included in each regression.

Each column is a regression on the change in points in the AP poll on game characteristics.

See the data appendix for further details and variable definifions. 
Table 7

Season, Team Effects and Clustered Standard Error Estimates

Win

Lose

Close Win

Close Loss

Blowout Win

Blowout Loss

Opponent Strength

Win * Opponent Strength

Lose * Opponent Strength

Win Late in Season?

Lose Late in Season?

\begin{tabular}{|c|c|c|c|c|c|c|c|}
\hline $\mathrm{I}$ & II & III & IV & $\mathrm{V}$ & VI & VII & VIII \\
\hline $187.7 * * *$ & $245.9 * * *$ & $187.7 * * *$ & $245.9 * * *$ & $187.7 * * *$ & $245.9^{* * *}$ & $192.3^{* *}$ & $250.6^{* * *}$ \\
\hline [2.74] & [3.43] & [2.94] & [3.14] & [3.00] & [2.94] & [2.60] & [3.17] \\
\hline$-301.9 * * *$ & $-258.5^{* * *}$ & $-301.9 * * *$ & $-258.5^{* * *}$ & $-301.9 * * *$ & $-258.5^{* *}$ & $-300.3^{* * *}$ & $-257.0^{* *}$ \\
\hline$[-4.28]$ & {$[-3.47]$} & {$[-4.62]$} & {$[-3.23]$} & {$[-4.34]$} & {$[-2.60]$} & {$[-3.81]$} & {$[-2.87]$} \\
\hline-10.16 & -12.24 & -10.16 & -12.24 & -10.16 & -12.24 & -8.641 & -10.66 \\
\hline [-1.02] & [-1.16] & [-0.93] & {$[-0.93]$} & {$[-0.90]$} & {$[-1.00]$} & {$[-0.80]$} & [-1.11] \\
\hline $29.46 * *$ & $29.59 * *$ & 29.46 & 29.59 & 29.46 & 29.59 & 29.48 & 29.44 \\
\hline$[2.10]$ & [1.99] & {$[1.41]$} & [1.14] & [1.36] & [1.23] & [1.05] & [1.09] \\
\hline $16.33^{* *}$ & $26.38^{* * *}$ & $16.33^{* * *}$ & $26.38^{* * *}$ & $16.33^{*}$ & $26.38^{* * *}$ & $16.72^{* *}$ & $26.85^{* * *}$ \\
\hline [2.29] & [3.47] & [2.99] & [4.57] & [2.04] & [3.02] & [2.39] & [4.79] \\
\hline$-48.83^{* * *}$ & $-53.31 * * *$ & $-48.83^{* *}$ & $-53.31 *$ & $-48.83^{* *}$ & $-53.31 * *$ & -48.83 & -53.19 \\
\hline [-3.19] & {$[-3.21]$} & {$[-2.23]$} & {$[-1.78]$} & {$[-2.21]$} & {$[-2.14]$} & {$[-1.54]$} & [-1.39] \\
\hline 2.401 & 3.523 & 2.401 & 3.523 & 2.401 & 3.523 & 2.448 & 3.535 \\
\hline [0.52] & {$[0.72]$} & [0.49] & [0.56] & [0.38] & [0.44] & [0.42] & [0.54] \\
\hline 2.387 & 2.087 & 2.387 & 2.087 & 2.387 & 2.087 & 2.395 & 2.126 \\
\hline$[0.51]$ & {$[0.42]$} & [0.49] & {$[0.33]$} & {$[0.41]$} & {$[0.27]$} & {$[0.41]$} & {$[0.33]$} \\
\hline $9.289 *$ & $9.120^{*}$ & $9.289 *$ & 9.12 & 9.289 & 9.12 & 9.235 & 9.088 \\
\hline [1.89] & [1.75] & [1.86] & [1.45] & [1.35] & [1.11] & [1.41] & [1.26] \\
\hline-0.6 & -8.167 & -0.6 & -8.167 & -0.6 & -8.167 & 0.501 & -7.047 \\
\hline$[-0.062]$ & {$[-0.81]$} & {$[-0.086]$} & {$[-1.06]$} & [-0.089] & {$[-1.08]$} & {$[0.084]$} & {$[-1.10]$} \\
\hline $54.96^{* * *}$ & $53.59 * * *$ & $54.96^{* * *}$ & $53.59 * *$ & $54.96^{* * *}$ & $53.59 * *$ & $54.99 * * *$ & $53.49 * * *$ \\
\hline [3.87] & [3.55] & [3.28] & [2.60] & [3.19] & [2.54] & [5.08] & [3.50] \\
\hline$X$ & $\mathrm{X}$ & $\mathrm{X}$ & $X$ & $X$ & $\mathrm{X}$ & $X$ & $X$ \\
\hline \multirow[t]{5}{*}{$\mathrm{X}$} & $\mathrm{X}$ & $\mathrm{X}$ & $\mathrm{X}$ & $\mathrm{X}$ & $\mathrm{X}$ & $\mathrm{X}$ & $\mathrm{X}$ \\
\hline & $\mathrm{X}$ & & $\mathrm{X}$ & & X & & $\mathrm{X}$ \\
\hline & & $\mathrm{X}$ & $\mathrm{X}$ & & & & \\
\hline & & & & $\mathrm{X}$ & $\mathrm{X}$ & & \\
\hline & & & & & & $\mathrm{X}$ & $\mathrm{X}$ \\
\hline 3846 & 3846 & 3846 & 3846 & 3846 & 3846 & 3845 & 3845 \\
\hline 0.52 & 0.57 & 0.52 & 0.57 & 0.52 & 0.57 & 0.52 & 0.57 \\
\hline
\end{tabular}

Blowout/Close Win/Loss *Home/Away * Opp. Strength

Season Effects, Team Effects

Season, Team, Season * Team Effects

Cluster on Season

Cluster on Team

T statistics in brackets $\left[{ }^{* * *} \mathrm{p}<.01,{ }^{* *} \mathrm{p}<.05,{ }^{*} \mathrm{p}<0.1\right]$ Each column is a regression on the change in points in the AP poll on game characteristics.

Cluster on Week of Season

\begin{tabular}{|c|c|c|c|c|c|c|c|c|}
\hline Observations & 3846 & 3846 & 3846 & 3846 & 3846 & 3846 & 3845 & 3845 \\
\hline $\mathrm{R}$-squared & 0.52 & 0.57 & 0.52 & 0.57 & 0.52 & 0.57 & 0.52 & 0.57 \\
\hline
\end{tabular}

See the data appendix for further description and variable definitions. 
Table 8

Summary Statistics For Late Season Games

\begin{tabular}{|c|c|c|c|c|}
\hline Variable & $\begin{array}{c}\text { Week } 8 \text { \& After } \\
\text { Mean }\end{array}$ & $\begin{array}{c}\text { Week } 9 \& \text { After } \\
\text { Mean }\end{array}$ & $\begin{array}{c}\text { Week } 10 \& \text { After } \\
\text { Mean }\end{array}$ & $\begin{array}{c}\text { Week } 11 \text { \& After } \\
\text { Mean }\end{array}$ \\
\hline Points Change & $\begin{array}{c}0.73 \\
(184.2)\end{array}$ & $\begin{array}{c}-0.57 \\
(181.9)\end{array}$ & $\begin{array}{c}-0.93 \\
(176.7)\end{array}$ & $\begin{array}{c}-5.34 \\
(172.3)\end{array}$ \\
\hline Rank Change & $\begin{array}{c}-0.02 \\
(3.0)\end{array}$ & $\begin{array}{l}0.00 \\
(2.9)\end{array}$ & $\begin{array}{c}-0.01 \\
(2.9)\end{array}$ & $\begin{array}{l}0.02 \\
(2.9)\end{array}$ \\
\hline Points Before Game & $\begin{array}{l}885.79 \\
(455.0)\end{array}$ & $\begin{array}{l}889.07 \\
(455.5)\end{array}$ & $\begin{array}{l}893.88 \\
(456.0)\end{array}$ & $\begin{array}{l}899.74 \\
(456.9)\end{array}$ \\
\hline Points After Game & $\begin{array}{l}880.67 \\
(456.6)\end{array}$ & $\begin{array}{l}883.77 \\
(457.0)\end{array}$ & $\begin{array}{l}887.33 \\
(457.5)\end{array}$ & $\begin{array}{l}887.16 \\
(460.3)\end{array}$ \\
\hline Rank Before Game & $\begin{array}{c}10.42 \\
(6.7)\end{array}$ & $\begin{array}{c}10.38 \\
(6.7)\end{array}$ & $\begin{array}{c}10.37 \\
(6.7)\end{array}$ & $\begin{array}{c}10.36 \\
(6.7)\end{array}$ \\
\hline Rank After Game & $\begin{array}{c}10.35 \\
(6.6)\end{array}$ & $\begin{array}{c}10.36 \\
(6.7)\end{array}$ & $\begin{array}{c}10.33 \\
(6.7)\end{array}$ & $\begin{array}{c}10.35 \\
(6.7)\end{array}$ \\
\hline Win & $\begin{array}{l}0.73 \\
(0.4)\end{array}$ & $\begin{array}{l}0.74 \\
(0.4)\end{array}$ & $\begin{array}{l}0.75 \\
(0.4)\end{array}$ & $\begin{array}{l}0.76 \\
(0.4)\end{array}$ \\
\hline Loss & $\begin{array}{l}0.26 \\
(0.4)\end{array}$ & $\begin{array}{l}0.25 \\
(0.4)\end{array}$ & $\begin{array}{l}0.24 \\
(0.4)\end{array}$ & $\begin{array}{l}0.23 \\
(0.4)\end{array}$ \\
\hline Tie & $\begin{array}{l}0.01 \\
(0.1)\end{array}$ & $\begin{array}{l}0.01 \\
(0.1)\end{array}$ & $\begin{array}{l}0.01 \\
(0.1)\end{array}$ & $\begin{array}{l}0.01 \\
(0.1)\end{array}$ \\
\hline Score of Team & $\begin{array}{l}27.47 \\
(14.4)\end{array}$ & $\begin{array}{l}27.27 \\
(14.4)\end{array}$ & $\begin{array}{l}26.82 \\
(14.1)\end{array}$ & $\begin{array}{l}26.39 \\
(13.7)\end{array}$ \\
\hline Score of Opponent & $\begin{array}{l}20.06 \\
(12.3)\end{array}$ & $\begin{array}{l}20.37 \\
(12.3)\end{array}$ & $\begin{array}{l}20.53 \\
(12.3)\end{array}$ & $\begin{array}{l}21.02 \\
(12.1)\end{array}$ \\
\hline Margin of Victory & $\begin{array}{c}7.41 \\
(20.3)\end{array}$ & $\begin{array}{c}6.91 \\
(20.3)\end{array}$ & $\begin{array}{c}6.29 \\
(19.8)\end{array}$ & $\begin{array}{c}5.37 \\
(19.3)\end{array}$ \\
\hline Blowout Win & $\begin{array}{l}0.51 \\
(0.5)\end{array}$ & $\begin{array}{l}0.52 \\
(0.5)\end{array}$ & $\begin{array}{l}0.54 \\
(0.5)\end{array}$ & $\begin{array}{l}0.57 \\
(0.5)\end{array}$ \\
\hline Blowout Loss & $\begin{array}{l}0.10 \\
(0.3)\end{array}$ & $\begin{array}{l}0.10 \\
(0.3)\end{array}$ & $\begin{array}{l}0.09 \\
(0.3)\end{array}$ & $\begin{array}{l}0.09 \\
(0.3)\end{array}$ \\
\hline Close Win & $\begin{array}{l}0.07 \\
(0.3)\end{array}$ & $\begin{array}{l}0.07 \\
(0.3)\end{array}$ & $\begin{array}{l}0.06 \\
(0.2)\end{array}$ & $\begin{array}{l}0.06 \\
(0.2)\end{array}$ \\
\hline Close Loss & $\begin{array}{l}0.06 \\
(0.2)\end{array}$ & $\begin{array}{l}0.06 \\
(0.2)\end{array}$ & $\begin{array}{l}0.05 \\
(0.2)\end{array}$ & $\begin{array}{l}0.05 \\
(0.2)\end{array}$ \\
\hline
\end{tabular}

Author's Calculations. Standard errors under mean values in parentheses.

See the data appendix for definitions. 
Table 9

Alternative Definitions of Late Weeks of Season

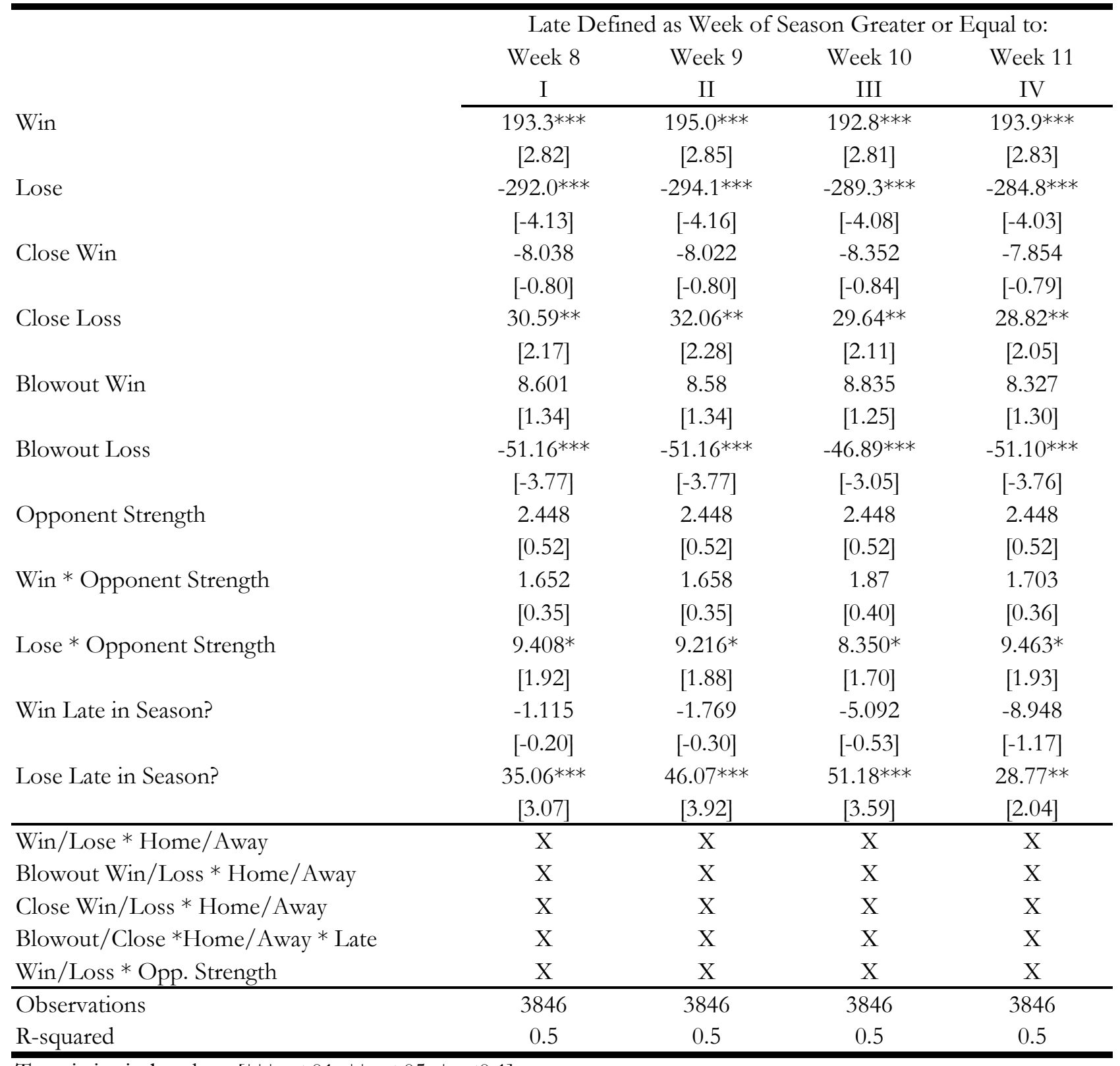

T statistics in brackets $\left[{ }^{* * *} \mathrm{p}<.01,{ }^{* *} \mathrm{p}<.05,{ }^{*} \mathrm{p}<0.1\right]$

Each column is a regression on the change in points in the AP poll on game characteristics.

See the data appendix for further details and variable definifions. 
Table 10

Strength of Opponent Check Using Games With Both Teams Ranked

\begin{tabular}{|c|c|c|c|c|c|c|}
\hline & $\mathrm{I}$ & II & III & IV & $\mathrm{V}$ & VI \\
\hline Win & $\begin{array}{c}248.4^{* * *} \\
{[5.94]}\end{array}$ & $\begin{array}{c}248.4^{* * *} \\
{[4.71]}\end{array}$ & $\begin{array}{c}256.3^{* * *} \\
{[4.81]}\end{array}$ & $\begin{array}{c}231.8^{* *} \\
{[2.53]}\end{array}$ & $\begin{array}{c}231.8^{* *} \\
{[2.09]}\end{array}$ & $\begin{array}{c}241.4^{* *} \\
{[2.28]}\end{array}$ \\
\hline Lose & $\begin{array}{c}-188.5^{* * *} \\
{[-3.03]}\end{array}$ & $\begin{array}{c}-188.5^{* * *} \\
{[-3.78]}\end{array}$ & $\begin{array}{c}-194.9^{* * *} \\
{[-4.17]}\end{array}$ & $\begin{array}{c}-303.0^{* *} \\
{[-2.49]}\end{array}$ & $\begin{array}{c}-303.0 * * \\
{[-2.79]}\end{array}$ & $\begin{array}{c}-297.8^{* * *} \\
{[-3.29]}\end{array}$ \\
\hline Close Win & $\begin{array}{l}-22.91 \\
{[-0.93]}\end{array}$ & $\begin{array}{l}-22.91 \\
{[-1.33]}\end{array}$ & $\begin{array}{l}-20.14 \\
{[-1.36]}\end{array}$ & $\begin{array}{l}-28.81 \\
{[-1.10]}\end{array}$ & $\begin{array}{l}-28.81 \\
{[-1.62]}\end{array}$ & $\begin{array}{l}-24.39 \\
{[-1.55]}\end{array}$ \\
\hline Close Loss & $\begin{array}{c}38.34^{*} \\
{[2.05]}\end{array}$ & $\begin{array}{l}38.34 \\
{[1.67]}\end{array}$ & $\begin{array}{l}41.51 \\
{[1.51]}\end{array}$ & $\begin{array}{c}38.1 \\
{[1.70]}\end{array}$ & $\begin{array}{c}38.1 \\
{[1.63]}\end{array}$ & $\begin{array}{l}38.81 \\
{[1.25]}\end{array}$ \\
\hline Blowout Win & $\begin{array}{l}-4.044 \\
{[-0.23]}\end{array}$ & $\begin{array}{l}-4.044 \\
{[-0.38]}\end{array}$ & $\begin{array}{c}-3.65 \\
{[-0.34]}\end{array}$ & $\begin{array}{l}-5.536 \\
{[-0.30]}\end{array}$ & $\begin{array}{l}-5.536 \\
{[-0.39]}\end{array}$ & $\begin{array}{c}-4.51 \\
{[-0.38]}\end{array}$ \\
\hline Blowout Loss & $\begin{array}{c}-66.03^{* * *} \\
{[-3.23]}\end{array}$ & $\begin{array}{c}-66.03 * * * \\
{[-4.18]}\end{array}$ & $\begin{array}{c}-64.37 * * \\
{[-2.52]}\end{array}$ & $\begin{array}{c}-75.08^{* * *} \\
{[-3.08]}\end{array}$ & $\begin{array}{c}-75.08^{* * *} \\
{[-4.07]}\end{array}$ & $\begin{array}{c}-75.40^{* *} \\
{[-2.51]}\end{array}$ \\
\hline Win Late in Season? & $\begin{array}{c}-35.13^{* *} \\
{[-2.73]}\end{array}$ & $\begin{array}{c}-35.13^{* *} \\
{[-2.77]}\end{array}$ & $\begin{array}{c}-35.62 * * \\
{[-2.32]}\end{array}$ & $\begin{array}{c}-38.39 * * \\
{[-2.79]}\end{array}$ & $\begin{array}{c}-38.39 * * * \\
{[-3.17]}\end{array}$ & $\begin{array}{c}-35.39 * * \\
{[-2.39]}\end{array}$ \\
\hline Lose Late in Season? & $\begin{array}{c}94.46^{* * *} \\
{[3.93]}\end{array}$ & $\begin{array}{c}94.46^{* * *} \\
{[4.47]}\end{array}$ & $\begin{array}{c}92.13^{* * *} \\
{[4.90]}\end{array}$ & $\begin{array}{c}72.26 * * \\
{[2.80]}\end{array}$ & $\begin{array}{c}72.26^{* * *} \\
{[3.12]}\end{array}$ & $\begin{array}{c}\text { 72.39*** } \\
{[3.90]}\end{array}$ \\
\hline Win * Opponent Rank & $\begin{array}{l}-100.9 \\
{[-1.11]}\end{array}$ & $\begin{array}{l}-100.9 \\
{[-0.84]}\end{array}$ & $\begin{array}{l}-87.15 \\
{[-0.84]}\end{array}$ & $\begin{array}{l}-24.11 \\
{[-0.29]}\end{array}$ & $\begin{array}{l}-24.11 \\
{[-0.20]}\end{array}$ & $\begin{array}{l}-18.58 \\
{[-0.20]}\end{array}$ \\
\hline Lose * Opponent Rank & $\begin{array}{c}-76.7 \\
{[-0.65]}\end{array}$ & $\begin{array}{c}-76.7 \\
{[-0.68]}\end{array}$ & $\begin{array}{l}-72.63 \\
{[-0.76]}\end{array}$ & $\begin{array}{l}-111.6 \\
{[-0.95]}\end{array}$ & $\begin{array}{l}-111.6 \\
{[-0.95]}\end{array}$ & $\begin{array}{l}-111.1 \\
{[-1.19]}\end{array}$ \\
\hline Opponent Strength & & & & $\begin{array}{l}-2.761 \\
{[-0.26]}\end{array}$ & $\begin{array}{l}-2.761 \\
{[-0.26]}\end{array}$ & $\begin{array}{l}-2.858 \\
{[-0.30]}\end{array}$ \\
\hline Win $*$ Opponent Strength & & & & $\begin{array}{c}-0.431 \\
{[-0.041]}\end{array}$ & $\begin{array}{c}-0.431 \\
{[-0.037]}\end{array}$ & $\begin{array}{c}0.106 \\
{[0.011]}\end{array}$ \\
\hline Lose $*$ Opponent Strength & & & & $\begin{array}{r}12.3 \\
{[1.12]} \\
\end{array}$ & $\begin{array}{r}12.3 \\
{[1.16]} \\
\end{array}$ & $\begin{array}{l}12.16 \\
{[1.37]} \\
\end{array}$ \\
\hline Win/Loss * Home /Away & $\mathrm{X}$ & $\mathrm{X}$ & $\mathrm{X}$ & $\mathrm{X}$ & $\mathrm{X}$ & $\mathrm{X}$ \\
\hline Close Win/Loss & $\mathrm{X}$ & $\mathrm{X}$ & $\mathrm{X}$ & $\mathrm{X}$ & $\mathrm{X}$ & $\mathrm{X}$ \\
\hline Blowout Win/Loss & $\mathrm{X}$ & $\mathrm{X}$ & $\mathrm{X}$ & $\mathrm{X}$ & $\mathrm{X}$ & $\mathrm{X}$ \\
\hline Close Win/Loss *Home/Away & $\mathrm{X}$ & $\mathrm{X}$ & $\mathrm{X}$ & $\mathrm{X}$ & $\mathrm{X}$ & $\mathrm{X}$ \\
\hline Blowout Win/Loss *Home/Away & $\mathrm{X}$ & $\mathrm{X}$ & $\mathrm{X}$ & $\mathrm{X}$ & $\mathrm{X}$ & $\mathrm{X}$ \\
\hline Blowout/Close * Win/Loss * Late in Season & $\mathrm{X}$ & $\mathrm{X}$ & $\mathrm{X}$ & $\mathrm{X}$ & $\mathrm{X}$ & $\mathrm{X}$ \\
\hline Blowout Win/Loss * Home/Away * Opp Str & & & & $\mathrm{X}$ & $\mathrm{X}$ & $\mathrm{X}$ \\
\hline Season, Team Effects & $\mathrm{X}$ & $\mathrm{X}$ & $\mathrm{X}$ & $\mathrm{X}$ & $\mathrm{X}$ & $\mathrm{X}$ \\
\hline Sean * Team Effects & $\mathrm{X}$ & $\mathrm{X}$ & $\mathrm{X}$ & $\mathrm{X}$ & $\mathrm{X}$ & $\mathrm{X}$ \\
\hline Team Cluster & $\mathrm{X}$ & & & $\mathrm{X}$ & & \\
\hline Season Cluster & & $\mathrm{X}$ & & & $\mathrm{X}$ & \\
\hline Week of Season Cluster & & & $\mathrm{X}$ & & & $\mathrm{X}$ \\
\hline Observations & 1348 & 1348 & 1309 & 1115 & 1115 & 1114 \\
\hline R-squared & 0.59 & 0.59 & 0.6 & 0.61 & 0.61 & 0.62 \\
\hline
\end{tabular}

T statistics in brackets $\left[{ }^{* *} \mathrm{p}<.01,{ }^{* *} \mathrm{p}<.05,{ }^{*} \mathrm{p}<0.1\right]$. Opponent rank is defined as $1 /$ Ranking, so that teams of higher rank are ranked higher. Each column is a regression on the change in points in the AP poll on game characteristics.

See the data appendix for further description and variable definitions. 
Table 11

Margin of Victory Check using Game Point Differential

\begin{tabular}{|c|c|c|c|c|c|c|}
\hline & $\mathrm{I}$ & II & III & IV & V & VI \\
\hline Win & $\begin{array}{c}189.1 * * * \\
{[2.76]}\end{array}$ & $\begin{array}{c}190.9 * * * \\
{[2.79]}\end{array}$ & $\begin{array}{c}174.2^{* *} \\
{[2.53]}\end{array}$ & $\begin{array}{c}167.4^{* *} \\
{[2.57]}\end{array}$ & $\begin{array}{c}167.4^{* *} \\
{[2.48]}\end{array}$ & $\begin{array}{c}163.7^{* *} \\
{[2.46]}\end{array}$ \\
\hline Lose & $\begin{array}{c}-285.3^{* * *} \\
{[-4.03]}\end{array}$ & $\begin{array}{c}-290.2^{* * *} \\
{[-4.10]}\end{array}$ & $\begin{array}{c}-277.1 * * * \\
{[-3.91]}\end{array}$ & $\begin{array}{c}-312.7 * * * \\
{[-4.81]}\end{array}$ & $\begin{array}{c}-312.7 * * * \\
{[-5.04]}\end{array}$ & $\begin{array}{c}-302.6^{* * *} \\
{[-3.98]}\end{array}$ \\
\hline Point Differential & $\begin{array}{l}0.418 \\
{[1.48]}\end{array}$ & $\begin{array}{l}0.127 \\
{[0.42]}\end{array}$ & & & & \\
\hline Losing Differential & & & $\begin{array}{c}3.074 * * \\
{[2.49]}\end{array}$ & $\begin{array}{l}-0.759 \\
{[-0.31]}\end{array}$ & $\begin{array}{l}-0.759 \\
{[-0.20]}\end{array}$ & $\begin{array}{c}0.171 \\
{[0.078]}\end{array}$ \\
\hline Winning Differential & & & $\begin{array}{l}0.271 \\
{[0.93]}\end{array}$ & $\begin{array}{c}0.0962 \\
{[0.27]}\end{array}$ & $\begin{array}{c}0.0962 \\
{[0.30]}\end{array}$ & $\begin{array}{l}0.183 \\
{[0.90]}\end{array}$ \\
\hline Opponent Strength & & $\begin{array}{l}2.448 \\
{[0.52]}\end{array}$ & $\begin{array}{l}2.448 \\
{[0.52]}\end{array}$ & $\begin{array}{l}2.321 \\
{[0.36]}\end{array}$ & $\begin{array}{l}2.321 \\
{[0.47]}\end{array}$ & $\begin{array}{l}2.382 \\
{[0.41]}\end{array}$ \\
\hline Differential * Opponent Strength & & $\begin{array}{c}-0.109 * * \\
{[-2.83]}\end{array}$ & & & & \\
\hline Winning Differential * Opponent Strength & & & & $\begin{array}{c}-0.192 * * * \\
{[-5.91]}\end{array}$ & $\begin{array}{c}-0.192 * * * \\
{[-5.90]}\end{array}$ & $\begin{array}{c}-0.189 * * * \\
{[-4.75]}\end{array}$ \\
\hline Losing Differential * Opponent Strength & & & & $\begin{array}{c}0.559 * * \\
{[2.29]}\end{array}$ & $\begin{array}{l}0.559 \\
{[1.18]}\end{array}$ & $\begin{array}{c}0.517 * \\
{[1.92]}\end{array}$ \\
\hline Win Late in Season? & $\begin{array}{c}-5.19 \\
{[-0.54]}\end{array}$ & $\begin{array}{c}-6.17 \\
{[-0.64]}\end{array}$ & $\begin{array}{c}-5.16 \\
{[-0.54]}\end{array}$ & $\begin{array}{c}-2.45 \\
{[-0.37]}\end{array}$ & $\begin{array}{l}-2.45 \\
{[-0.37]}\end{array}$ & $\begin{array}{l}-0.838 \\
{[-0.14]}\end{array}$ \\
\hline Lose Late in Season? & $\begin{array}{c}51.13^{* * *} * \\
{[3.58]} \\
\end{array}$ & $\begin{array}{c}51.24 * * * \\
{[3.59]} \\
\end{array}$ & $\begin{array}{c}50.89 * * * \\
{[3.57]} \\
\end{array}$ & $\begin{array}{c}54.61 * * * \\
{[3.10]} \\
\end{array}$ & $\begin{array}{c}54.61 * * * \\
{[3.22]} \\
\end{array}$ & $\begin{array}{c}54.28 * * * \\
{[5.48]}\end{array}$ \\
\hline Win/Loss * Home / Away & $\mathrm{X}$ & $\mathrm{X}$ & $\mathrm{X}$ & $\mathrm{X}$ & $\mathrm{X}$ & $\mathrm{X}$ \\
\hline Win/Loss * Opp Strength & $\mathrm{X}$ & $\mathrm{X}$ & $\mathrm{X}$ & $\mathrm{X}$ & $\mathrm{X}$ & $\mathrm{X}$ \\
\hline Season, Team Effects & & & & $\mathrm{X}$ & $\mathrm{X}$ & $\mathrm{X}$ \\
\hline Sean * Team Effects & & & & $\mathrm{X}$ & $\mathrm{X}$ & $\mathrm{X}$ \\
\hline Team Cluster & & & & $\mathrm{X}$ & & \\
\hline Season Cluster & & & & & $\mathrm{X}$ & \\
\hline Week of Season Cluster & & & & & & $\mathrm{X}$ \\
\hline Observations & 3846 & 3846 & 3846 & 3846 & 3846 & 3845 \\
\hline R-squared & 0.5 & 0.5 & 0.5 & 0.52 & 0.52 & 0.52 \\
\hline
\end{tabular}

T statistics in brackets $\left[{ }^{* * *} \mathrm{p}<.01,{ }^{*} \mathrm{p}<.05,{ }^{*} \mathrm{p}<0.1\right]$. Differential is defined as the point differential

such that losing teams have negative point differentials and winning teams have positive point differentials.

Each column is a regression on the change in points in the AP poll on game characteristics.

See the data appendix for further description and variable definitions. 
Appendix Table A

Truncation Check: Point Results for Teams Ranked 1-20 Only

\begin{tabular}{|c|c|c|c|c|c|}
\hline & $\mathrm{I}$ & II & III & IV & $\mathrm{V}$ \\
\hline \multirow[t]{2}{*}{ Win } & $190.8^{* * *}$ & $190.8^{* * *}$ & $248.2^{* * *}$ & $248.2^{* * *}$ & $252.2^{* * *}$ \\
\hline & [2.90] & [2.89] & [3.23] & [3.58] & {$[3.36]$} \\
\hline \multirow[t]{2}{*}{ Lose } & $-316.0^{* * *}$ & $-312.5^{* * *}$ & $-269.7 * * *$ & $-269.7 * * *$ & $-268.4^{* * *}$ \\
\hline & {$[-4.64]$} & {$[-4.58]$} & {$[-2.81]$} & {$[-3.78]$} & {$[-2.97]$} \\
\hline \multirow[t]{2}{*}{ Close Win } & -10.69 & -10.91 & -14.06 & -14.06 & -12.69 \\
\hline & {$[-1.06]$} & {$[-1.09]$} & {$[-1.27]$} & {$[-1.03]$} & {$[-1.07]$} \\
\hline \multirow[t]{2}{*}{ Close Loss } & $32.10^{* *}$ & $31.67 * *$ & 29.62 & 29.62 & 29.24 \\
\hline & {$[2.32]$} & {$[2.29]$} & {$[1.36]$} & [1.13] & {$[1.07]$} \\
\hline \multirow[t]{2}{*}{ Blowout Win } & 6.363 & 6.078 & $19.88^{* * *}$ & $19.88^{* * *}$ & $20.32 * * *$ \\
\hline & [1.00] & {$[0.86]$} & {$[2.97]$} & {$[3.12]$} & {$[3.03]$} \\
\hline \multirow[t]{2}{*}{ Blowout Loss } & $-61.93^{* * *}$ & $-60.58^{* * *}$ & $-63.49 * *$ & $-63.49 *$ & -63.57 \\
\hline & {$[-4.59]$} & {$[-3.95]$} & {$[-2.21]$} & {$[-1.91]$} & {$[-1.47]$} \\
\hline \multirow[t]{2}{*}{ Opponent Strength } & 2.697 & 2.697 & 3.535 & 3.535 & 3.55 \\
\hline & {$[0.60]$} & {$[0.60]$} & {$[0.44]$} & {$[0.54]$} & {$[0.52]$} \\
\hline \multirow[t]{2}{*}{ Win * Opponent Strength } & 1.017 & 1.164 & 1.267 & 1.267 & 1.301 \\
\hline & [0.22] & {$[0.26]$} & [0.16] & [0.19] & {$[0.19]$} \\
\hline \multirow[t]{2}{*}{ Lose * Opponent Strength } & $10.85^{* *}$ & $10.14^{* *}$ & 11.05 & $11.05^{*}$ & 11.04 \\
\hline & {$[2.28]$} & {$[2.13]$} & [1.29] & {$[1.73]$} & {$[1.51]$} \\
\hline \multirow[t]{2}{*}{ Win Late in Season? } & -8.059 & -10.19 & $-14.04 *$ & $-14.04 * *$ & $-13.01 *$ \\
\hline & {$[-1.24]$} & {$[-1.05]$} & {$[-1.87]$} & {$[-2.21]$} & {$[-1.83]$} \\
\hline \multirow[t]{2}{*}{ Lose Late in Season? } & $52.69 * * *$ & $53.60 * * *$ & $52.48^{* *}$ & $52.48^{* *}$ & $52.13^{* * *}$ \\
\hline & {$[4.30]$} & {$[3.83]$} & {$[2.38]$} & {$[2.37]$} & [2.94] \\
\hline Win/Loss * Home /Away & $\mathrm{X}$ & $\mathrm{X}$ & $\mathrm{X}$ & $\mathrm{X}$ & $\mathrm{X}$ \\
\hline Win/Loss * Opp Strength & $\mathrm{X}$ & $\mathrm{X}$ & $\mathrm{X}$ & $\mathrm{X}$ & $\mathrm{X}$ \\
\hline Close Win/Loss *Home/Away & $\mathrm{X}$ & $\mathrm{X}$ & $\mathrm{X}$ & $\mathrm{X}$ & $\mathrm{X}$ \\
\hline Blowout Win/Loss *Home/Away & $\mathrm{X}$ & $\mathrm{X}$ & $\mathrm{X}$ & $\mathrm{X}$ & $\mathrm{X}$ \\
\hline Blowout/Close $*$ Win/Loss * Late in Season & & $\mathrm{X}$ & $\mathrm{X}$ & $\mathrm{X}$ & $\mathrm{X}$ \\
\hline Blowout Win/Loss * Home/Away * Opp Str & & $\mathrm{X}$ & $\mathrm{X}$ & $\mathrm{X}$ & $\mathrm{X}$ \\
\hline Season, Team Effects, Season * Team Effects & & & $\mathrm{X}$ & $\mathrm{X}$ & $\mathrm{X}$ \\
\hline Team Cluster & & & $\mathrm{X}$ & & \\
\hline Season Cluster & & & & $\mathrm{X}$ & \\
\hline Week of Season Cluster & & & & & $\mathrm{X}$ \\
\hline Observations & 3590 & 3590 & 3590 & 3590 & 3589 \\
\hline R-squared & 0.53 & 0.53 & 0.6 & 0.6 & 0.6 \\
\hline
\end{tabular}

T statistics in brackets [ $\left.{ }^{* * *} \mathrm{p}<.01,{ }^{* *} \mathrm{p}<.05,{ }^{*} \mathrm{p}<0.1\right]$

Each column is a regression on the change in points in the AP poll on game characteristics.

Only Teams Ranked 1-20 before the game was played are included in these regressions.

See the data appendix for further description and variable definitions. 
Appendix Table B

Truncation Check: Ranking Results with Imputed Rankings

Win

Lose

Close Win

\section{Close Loss}

Blowout Win

Blowout Loss

Opponent Strength

Win Late in Season?

Lose Late in Season?

$-5$

$-5.419 * * * \quad-3.912 * *$

[-9.10]

$2.895^{* * *}$

[-2.41]

[4.95]

$-0.122$

[-0.51]

$-0.982 * * *$

[-3.20]

$-0.0644$

[-0.42]

0.268

[0.84]

$-0.107 * * *$

[-8.15]

$-0.229$

[-1.45]

$5.422 * * *$

[3.28]

$[3.28]$
-0.123

[-0.52]

$-0.986 * * *$

[-3.21]

$-0.0686$

[-0.45]

0.205

[0.64]

$[0.64]$
$-0.106 * * *$
$[-8.11]$

$-0.221$

[-1.40]

$\begin{array}{cc}-1.039 * * * & -1.112 * * * \\ {[-3.24]} & {[-3.45]}\end{array}$

Win/Loss * Home / Away

Win/Loss * Opp Strength

Blowout/Close Win/Loss* Home/Away* Opp Strength

Season Effects, Team Effects

Season * Team Effects

Cluster on Team

Cluster on Season

$\mathrm{X}$

Cluster on Week of Season

Observations

R-squared

$\begin{array}{cc}4350 & 4350 \\ 0.41 & 0.41\end{array}$

4350
0.43

IV

$\frac{\mathrm{V}}{-3.648 * * *}$

VI
VII

$\begin{array}{lllll}-3.648 * * & -3.755^{* *} & -3.648^{* * *} & -3.648 * * * & -3.683 * * *\end{array}$

$[-2.26] \quad[-2.34]$

$[-5.69]$

$[-5.43]$

[-7.05]

$5.755^{* * * *}$

$5.742 * * *$

$5.755^{* * *}$

$5.755^{* * *}$

$5.745^{* * *}$

$-0.085$

[3.48]

[7.61]

[7.35]

[5.92]

[-0.36]

[0.17]

$-0.085$

$-0.085$

$-0.0956$

$-0.890 * * *$

$-0.704 * *$

$-0.890^{* *}$

[-0.39]

[-0.36]

[-2.91]

[-2.26]

[-2.45]

$-0.890 * *$

$-0.891 *$

$-0.187$

$-0.455^{* * *}$

$-0.187$

[-2.41]

[-1.77]

[-1.22]

[-2.95]

[-1.19]

$-0.188 * *$

[0.80]

$-0.115^{* * *}$

0.519

0.257

0.257

[-2.14]

[1.57] [0.41]

$-0.128^{* * *}$

$0.115^{* * *}$

[0.68]

0.257

[-8.79] [-9.84]

$-0.286 *$

$-0.0372$

[-5.50]

$-0.115^{* * *}$

[0.50]

[-1.79]

[-0.24]

$-0.286$

[-7.88]

$-0.286 * *$

$-0.116^{* * *}$

[-1.30]

[-2.14]

[-7.62]

-0.291 **

T statistics in brackets $\left[{ }^{* * *} \mathrm{p}<.01,{ }^{*} \mathrm{p}<.05,{ }^{*} \mathrm{p}<0.1\right]$. Teams unranked before or after the game are given a missing rank of 30 .

$\begin{array}{cc}{[-3.09]} & {[-2.55]} \\ \mathrm{X} & \mathrm{X}\end{array}$

$\mathrm{X} \quad \mathrm{X}$

$\begin{array}{cc}-3.38] & {[-3.0} \\ X & X\end{array}$

$\begin{array}{lll}X & X & X \\ X & X & X \\ X & X\end{array}$

-2.55] $\quad[-3.75] \quad[-3.45]$

Each column is a regression on the change in rank in the AP poll on game characteristics.

See the data appendix for further description and variable definitions. 
Appendix Table C

Truncation Check: Eliminating Bowl Games and Conference Championship Games

\begin{tabular}{|c|c|c|c|c|c|c|}
\hline & $\mathrm{I}$ & II & III & IV & V & VI \\
\hline Win & $\begin{array}{c}197.8^{* * *} \\
{[2.89]}\end{array}$ & $\begin{array}{c}196.3^{* * *} \\
{[2.86]}\end{array}$ & $\begin{array}{c}252.6^{* * *} \\
{[3.51]}\end{array}$ & $\begin{array}{c}193.0^{* * *} \\
{[3.10]}\end{array}$ & $\begin{array}{c}193.0 * * * \\
{[3.04]}\end{array}$ & $\begin{array}{c}193.0 * * \\
{[2.58]}\end{array}$ \\
\hline Lose & $\begin{array}{c}-312.1 * * * \\
{[-4.38]}\end{array}$ & $\begin{array}{c}-306.6^{* * *} \\
{[-4.30]}\end{array}$ & $\begin{array}{c}-272.7 * * * \\
{[-3.63]}\end{array}$ & $\begin{array}{c}-319.0^{* * *} \\
{[-4.41]}\end{array}$ & $\begin{array}{c}-319.0 * * * \\
{[-4.79]}\end{array}$ & $\begin{array}{c}-319.0 * * * \\
{[-3.77]}\end{array}$ \\
\hline Close Win & $\begin{array}{c}-4.9 \\
{[-0.49]}\end{array}$ & $\begin{array}{l}-5.138 \\
{[-0.51]}\end{array}$ & $\begin{array}{l}-9.613 \\
{[-0.90]}\end{array}$ & $\begin{array}{l}-6.942 \\
{[-0.61]}\end{array}$ & $\begin{array}{l}-6.942 \\
{[-0.63]}\end{array}$ & $\begin{array}{l}-6.942 \\
{[-0.63]}\end{array}$ \\
\hline Close Loss & $\begin{array}{c}28.67^{* *} \\
{[2.03]}\end{array}$ & $\begin{array}{c}28.10^{* *} \\
{[1.99]}\end{array}$ & $\begin{array}{c}28.00^{*} \\
{[1.87]}\end{array}$ & $\begin{array}{l}28.25 \\
{[1.29]}\end{array}$ & $\begin{array}{l}28.25 \\
{[1.38]}\end{array}$ & $\begin{array}{l}28.25 \\
{[1.00]}\end{array}$ \\
\hline Blowout Win & $\begin{array}{l}9.094 \\
{[1.41]}\end{array}$ & $\begin{array}{l}9.876 \\
{[1.38]}\end{array}$ & $\begin{array}{c}27.57 * * * \\
{[3.60]}\end{array}$ & $\begin{array}{c}17.52^{* *} \\
{[2.19]}\end{array}$ & $\begin{array}{c}17.52^{* * *} \\
{[3.19]}\end{array}$ & $\begin{array}{c}17.52^{* *} \\
{[2.48]}\end{array}$ \\
\hline Blowout Loss & $\begin{array}{c}-51.91 * * * \\
{[-3.78]}\end{array}$ & $\begin{array}{c}-54.42 * * * \\
{[-3.48]}\end{array}$ & $\begin{array}{c}-59.52 * * * \\
{[-3.52]}\end{array}$ & $\begin{array}{c}-55.85^{* *} \\
{[-2.34]}\end{array}$ & $\begin{array}{c}-55.85^{* *} \\
{[-2.64]}\end{array}$ & $\begin{array}{l}-55.85 \\
{[-1.67]}\end{array}$ \\
\hline Opponent Strength & $\begin{array}{l}2.448 \\
{[0.52]}\end{array}$ & $\begin{array}{l}2.448 \\
{[0.52]}\end{array}$ & $\begin{array}{c}3.56 \\
{[0.72]}\end{array}$ & $\begin{array}{l}2.473 \\
{[0.39]}\end{array}$ & $\begin{array}{l}2.473 \\
{[0.50]}\end{array}$ & $\begin{array}{l}2.473 \\
{[0.42]}\end{array}$ \\
\hline Win * Opponent Strength & $\begin{array}{l}1.698 \\
{[0.36]}\end{array}$ & $\begin{array}{l}1.921 \\
{[0.41]}\end{array}$ & $\begin{array}{l}2.132 \\
{[0.43]}\end{array}$ & $\begin{array}{l}2.377 \\
{[0.40]}\end{array}$ & $\begin{array}{l}2.377 \\
{[0.49]}\end{array}$ & $\begin{array}{l}2.377 \\
{[0.40]}\end{array}$ \\
\hline Lose * Opponent Strength & $\begin{array}{c}8.748^{*} \\
{[1.78]}\end{array}$ & $\begin{array}{l}8.073 \\
{[1.64]}\end{array}$ & $\begin{array}{c}9.027^{*} \\
{[1.73]}\end{array}$ & $\begin{array}{l}9.023 \\
{[1.30]}\end{array}$ & $\begin{array}{c}9.023^{*} \\
{[1.80]}\end{array}$ & $\begin{array}{l}9.023 \\
{[1.37]}\end{array}$ \\
\hline Win Late in Season? & $\begin{array}{l}-3.241 \\
{[-0.49]}\end{array}$ & $\begin{array}{l}-3.135 \\
{[-0.32]}\end{array}$ & $\begin{array}{l}-7.475 \\
{[-0.72]}\end{array}$ & $\begin{array}{c}0.644 \\
{[0.097]}\end{array}$ & $\begin{array}{c}0.644 \\
{[0.090]}\end{array}$ & $\begin{array}{l}0.644 \\
{[0.11]}\end{array}$ \\
\hline Lose Late in Season? & $\begin{array}{c}46.81 * * * \\
{[3.67]}\end{array}$ & $\begin{array}{c}44.10^{* * *} \\
{[3.00]}\end{array}$ & $\begin{array}{c}46.09 * * * \\
{[2.97]}\end{array}$ & $\begin{array}{c}47.31 * * * \\
{[3.05]}\end{array}$ & $\begin{array}{c}47.31 * * * \\
{[2.94]}\end{array}$ & $\begin{array}{c}47.31 * * * \\
{[4.61]}\end{array}$ \\
\hline Win/Loss * Home /Away & $\mathrm{X}$ & $\mathrm{X}$ & $\mathrm{X}$ & $\mathrm{X}$ & $\mathrm{X}$ & $\mathrm{X}$ \\
\hline Close Win/Loss & $\mathrm{X}$ & $\mathrm{X}$ & $\mathrm{X}$ & $\mathrm{X}$ & $\mathrm{X}$ & $\mathrm{X}$ \\
\hline Blowout Win/Loss & $\mathrm{X}$ & $\mathrm{X}$ & $\mathrm{X}$ & $\mathrm{X}$ & $\mathrm{X}$ & $\mathrm{X}$ \\
\hline Win/Loss * Opp Strength & $\mathrm{X}$ & $\mathrm{X}$ & $\mathrm{X}$ & $\mathrm{X}$ & $\mathrm{X}$ & $\mathrm{X}$ \\
\hline Close Win/Loss *Home/Away & & $\mathrm{X}$ & $\mathrm{X}$ & $\mathrm{X}$ & $\mathrm{X}$ & $\mathrm{X}$ \\
\hline Blowout Win/Loss *Home/Away & & $\mathrm{X}$ & $\mathrm{X}$ & $\mathrm{X}$ & $\mathrm{X}$ & $\mathrm{X}$ \\
\hline Blowout/Close * Win/Loss * Late in Season & & $\mathrm{X}$ & $\mathrm{X}$ & $\mathrm{X}$ & $\mathrm{X}$ & $\mathrm{X}$ \\
\hline Blowout Win/Loss $*$ Home/Away $*$ Opp Str & & $\mathrm{X}$ & $\mathrm{X}$ & $\mathrm{X}$ & $\mathrm{X}$ & $\mathrm{X}$ \\
\hline Season, Team Effects, Season * Team Effects & & & $\mathrm{X}$ & $\mathrm{X}$ & $\mathrm{X}$ & $\mathrm{X}$ \\
\hline Team Cluster & & & & $\mathrm{X}$ & & \\
\hline Season Cluster & & & & & $\mathrm{X}$ & \\
\hline Week of Season Cluster & & & & & & $\mathrm{X}$ \\
\hline Observations & 3492 & 3492 & 3492 & 3492 & 3492 & 3492 \\
\hline R-squared & 0.5 & 0.5 & 0.57 & 0.52 & 0.52 & 0.52 \\
\hline
\end{tabular}

T statistics in brackets $\left[{ }^{* * *} \mathrm{p}<0.01,{ }^{* *} \mathrm{p}<0.05,{ }^{*} \mathrm{p}<0.1\right]$

Each column is a regression on the change in points in the AP poll on game characteristics.

Regressions include all games excpet championship games and bowl games. See the data appendix for the definition of variable 
Appendix Table E

Specification Check: Addition of Week of Season to the Specification

\begin{tabular}{|c|c|c|c|c|c|c|c|}
\hline & $\mathrm{I}$ & II & III & IV & $\mathrm{V}$ & VI & VII \\
\hline Win & $\begin{array}{c}192.8^{* * *} \\
{[2.81]}\end{array}$ & $\begin{array}{c}197.6^{* * *} \\
{[2.88]}\end{array}$ & $\begin{array}{c}250.8^{* * *} \\
{[3.19]}\end{array}$ & $\begin{array}{c}250.8^{* * *} \\
{[3.01]}\end{array}$ & $\begin{array}{c}250.8^{* * *} \\
{[3.18]}\end{array}$ & $\begin{array}{l}122.5 \\
{[1.55]}\end{array}$ & $\begin{array}{c}179.8^{* *} \\
{[2.17]}\end{array}$ \\
\hline Lose & $\begin{array}{c}-289.3^{* * *} \\
{[-4.08]}\end{array}$ & $\begin{array}{c}-287.6 * * * \\
{[-4.06]}\end{array}$ & $\begin{array}{c}-257.0^{* * *} \\
{[-3.22]}\end{array}$ & $\begin{array}{c}-257.0 * * \\
{[-2.58]}\end{array}$ & $\begin{array}{c}-257.0^{* *} \\
{[-2.87]}\end{array}$ & $\begin{array}{c}-352.1 * * * \\
{[-4.27]}\end{array}$ & $\begin{array}{c}-331.6^{* * *} \\
{[-3.81]}\end{array}$ \\
\hline Close Win & $\begin{array}{l}-8.352 \\
{[-0.84]}\end{array}$ & $\begin{array}{l}-6.842 \\
{[-0.68]}\end{array}$ & $\begin{array}{l}-10.65 \\
{[-0.81]}\end{array}$ & $\begin{array}{l}-10.65 \\
{[-0.88]}\end{array}$ & $\begin{array}{l}-10.65 \\
{[-1.11]}\end{array}$ & $\begin{array}{l}-6.778 \\
{[-0.68]}\end{array}$ & $\begin{array}{l}-10.56 \\
{[-1.00]}\end{array}$ \\
\hline Close Loss & $\begin{array}{c}29.64^{* *} \\
{[2.11]}\end{array}$ & $\begin{array}{c}29.65^{* *} \\
{[2.11]}\end{array}$ & $\begin{array}{l}29.46 \\
{[1.14]}\end{array}$ & $\begin{array}{l}29.46 \\
{[1.23]}\end{array}$ & $\begin{array}{l}29.46 \\
{[1.09]}\end{array}$ & $\begin{array}{c}29.62^{* *} \\
{[2.11]}\end{array}$ & $\begin{array}{c}29.65 * * \\
{[2.00]}\end{array}$ \\
\hline Blowout Win & $\begin{array}{l}8.835 \\
{[1.25]}\end{array}$ & $\begin{array}{l}9.261 \\
{[1.31]}\end{array}$ & $\begin{array}{c}26.89 * * * \\
{[4.71]}\end{array}$ & $\begin{array}{c}26.89 * * * \\
{[3.12]}\end{array}$ & $\begin{array}{c}26.89 * * * \\
{[4.85]}\end{array}$ & $\begin{array}{c}9.36 \\
{[1.32]}\end{array}$ & $\begin{array}{c}26.95^{* * *} \\
{[3.55]}\end{array}$ \\
\hline Blowout Loss & $\begin{array}{c}-46.89 * * * \\
{[-3.05]}\end{array}$ & $\begin{array}{c}-46.96 * * * \\
{[-3.06]}\end{array}$ & $\begin{array}{c}-53.28^{*} \\
{[-1.78]}\end{array}$ & $\begin{array}{c}-53.28^{* *} \\
{[-2.13]}\end{array}$ & $\begin{array}{l}-53.28 \\
{[-1.40]}\end{array}$ & $\begin{array}{c}-46.70^{* * *} \\
{[-3.04]}\end{array}$ & $\begin{array}{c}-53.36^{* * *} \\
{[-3.21]}\end{array}$ \\
\hline Opponent Strength & $\begin{array}{l}2.448 \\
{[0.52]}\end{array}$ & $\begin{array}{c}2.46 \\
{[0.53]}\end{array}$ & $\begin{array}{l}3.541 \\
{[0.56]}\end{array}$ & $\begin{array}{l}3.541 \\
{[0.44]}\end{array}$ & $\begin{array}{l}3.541 \\
{[0.54]}\end{array}$ & $\begin{array}{l}2.044 \\
{[0.44]}\end{array}$ & $\begin{array}{l}3.125 \\
{[0.64]}\end{array}$ \\
\hline Win * Opponent Strength & $\begin{array}{c}1.87 \\
{[0.40]}\end{array}$ & $\begin{array}{l}1.907 \\
{[0.40]}\end{array}$ & $\begin{array}{l}2.123 \\
{[0.34]}\end{array}$ & $\begin{array}{l}2.123 \\
{[0.28]}\end{array}$ & $\begin{array}{l}2.123 \\
{[0.33]}\end{array}$ & $\begin{array}{l}2.325 \\
{[0.49]}\end{array}$ & $\begin{array}{l}2.539 \\
{[0.51]}\end{array}$ \\
\hline Lose * Opponent Strength & $\begin{array}{c}8.350^{*} \\
{[1.70]}\end{array}$ & $\begin{array}{c}8.340^{*} \\
{[1.69]}\end{array}$ & $\begin{array}{l}9.091 \\
{[1.44]}\end{array}$ & $\begin{array}{l}9.091 \\
{[1.11]}\end{array}$ & $\begin{array}{l}9.091 \\
{[1.26]}\end{array}$ & $\begin{array}{c}8.748^{*} \\
{[1.78]}\end{array}$ & $\begin{array}{c}9.508^{*} \\
{[1.83]}\end{array}$ \\
\hline Win Late in Season? & $\begin{array}{l}-5.092 \\
{[-0.53]}\end{array}$ & $\begin{array}{l}-6.027 \\
{[-0.52]}\end{array}$ & $\begin{array}{l}-8.325 \\
{[-0.68]}\end{array}$ & $\begin{array}{l}-8.325 \\
{[-0.81]}\end{array}$ & $\begin{array}{l}-8.325 \\
{[-0.98]}\end{array}$ & $\begin{array}{l}-10.02 \\
{[-0.83]}\end{array}$ & $\begin{array}{l}-9.885 \\
{[-0.80]}\end{array}$ \\
\hline Lose Late in Season? & $\begin{array}{c}51.18^{* * *} \\
{[3.59]}\end{array}$ & $\begin{array}{c}49.32^{* * *} \\
{[3.15]}\end{array}$ & $\begin{array}{c}52.29 * * \\
{[2.75]}\end{array}$ & $\begin{array}{c}52.29 * * \\
{[2.64]}\end{array}$ & $\begin{array}{c}52.29 * * * \\
{[3.49]}\end{array}$ & $\begin{array}{c}56.35^{* * *} \\
{[2.66]}\end{array}$ & $\begin{array}{c}48.14^{* *} \\
{[2.12]}\end{array}$ \\
\hline Week of Season & & $\begin{array}{l}0.283 \\
{[0.29]}\end{array}$ & $\begin{array}{l}0.205 \\
{[0.16]}\end{array}$ & $\begin{array}{l}0.205 \\
{[0.19]}\end{array}$ & $\begin{array}{l}0.205 \\
{[0.23]}\end{array}$ & $\begin{array}{c}-9.919 * \\
{[-1.76]}\end{array}$ & $\begin{array}{c}-9.796^{*} \\
{[-1.65]}\end{array}$ \\
\hline Win * Week of Season & & & & & & $\begin{array}{l}10.81 * \\
{[1.89]}\end{array}$ & $\begin{array}{l}10.23^{*} \\
{[1.69]}\end{array}$ \\
\hline Lose $*$ Week of Season & & & & & & $\begin{array}{l}9.131 \\
{[1.49]}\end{array}$ & $\begin{array}{l}10.69 \\
{[1.64]}\end{array}$ \\
\hline Win/Loss * Home /Away & $\bar{X}$ & $\mathrm{X}$ & $\bar{X}$ & $\bar{X}$ & $\mathrm{X}$ & $\bar{X}$ & $\bar{X}$ \\
\hline Close $*$ Home/Away & $\mathrm{X}$ & $\mathrm{X}$ & $\mathrm{X}$ & $\mathrm{X}$ & $\mathrm{X}$ & $\mathrm{X}$ & $\mathrm{X}$ \\
\hline Blowout * Home/Away & $\mathrm{X}$ & $\mathrm{X}$ & $\mathrm{X}$ & $\mathrm{X}$ & $\mathrm{X}$ & $\mathrm{X}$ & $\mathrm{X}$ \\
\hline Close $*$ Home $/$ Away $*$ Late & $\mathrm{X}$ & $\mathrm{X}$ & $\mathrm{X}$ & $\mathrm{X}$ & $\mathrm{X}$ & $\mathrm{X}$ & $\mathrm{X}$ \\
\hline Blowout * Home/Away * Late & $\mathrm{X}$ & $\mathrm{X}$ & $\mathrm{X}$ & $\mathrm{X}$ & $\mathrm{X}$ & $\mathrm{X}$ & $\mathrm{X}$ \\
\hline Season, Team Effects & & & $\mathrm{X}$ & $\mathrm{X}$ & $\mathrm{X}$ & & $\mathrm{X}$ \\
\hline Season $*$ Team Effects & & & $\mathrm{X}$ & $\mathrm{X}$ & $\mathrm{X}$ & & $\mathrm{X}$ \\
\hline Season Cluster & & & $\mathrm{X}$ & & & & \\
\hline Team Cluster & & & & $\mathrm{X}$ & & & \\
\hline Week of Season Cluster & & & & & $\mathrm{X}$ & & \\
\hline Observations & 3846 & 3846 & 3846 & 3846 & 3846 & 3846 & 3846 \\
\hline R-squared & 0.5 & 0.5 & 0.57 & 0.57 & 0.57 & 0.5 & 0.57 \\
\hline
\end{tabular}

T statistics in brackets $\left[* * * \mathrm{p}<.01,{ }^{* *} \mathrm{p}<.05,{ }^{*} \mathrm{p}<0.1\right]$

Each column is a regression on the change in points in the AP poll on game characteristics. Column I is a replication of Column VI from Table 3.

See the data appendix for further description and variable definitions. 